\title{
WHEN IS A BRIBE NOT A BRIBE? A RE-EXAMINATION OF THE FCPA IN LIGHT OF BUSINESS REALITY
}

\author{
Beverley Earle* \& Anita Cava**
}

\begin{abstract}
The Foreign Corrupt Practices Act (FCPA) ushered in an era where the mantra was zero tolerance for illegal behavior. Yet the enforcement climate did not match the rhetoric and many in business did not take this legal obligation seriously. In 1988, Congress amended the FCPA to permit so-called "facilitation payments," thereby reflecting the reality of business. The amendment made explicit that some technical bribes might actually be paid not to obtain or retain business, but instead merely to move goods off a dock or to get them through customs. Ultimately the OECD nations joined the United States in the 1990s by passing the Anti-Bribery Convention and moving the community of nations towards a common understanding of the necessity of taking a legal stand against bribery. The United Kingdom and other countries have also passed new legislation to curtail the practice of bribery. Enforcement actions increased dramatically in the United States after President Bush and the new U.K. law reinforced this new enforcement environment. Yet questions persist: Has the zealousness to eradicate bribery, fueled by the great harm it does to a country's development, overshadowed common sense and business reality in a narrow set of cases?
\end{abstract}

* C2012 Earle \& Cava. B.A., University of Pennsylvania, J.D., Boston University School of Law; Gregory H. Adamian Professor of Law and Chair, Department of Law, Taxation and Financial Planning, Bentley University, Waltham, MA.

** B.A. with Distinction, Swarthmore College, J.D. New York University School of Law, Hays Fellow; Professor of Business Law, University of Miami School of Business Administration; Director of Business Ethics Program and Co-Director of University of Miami Ethics Programs.

The authors were invited to a symposium at the Wharton School of the University of Pennsylvania, Public Sector Corruption and Private Business Firms, June 28-29, 2012, http://gstdept.wharton.upenn.edu/corruption/, organized by Associate Professor Philip M. Nichols, The Wharton School of University of Pennsylvania and attended by Liz DavidBarrett (Said School of Business, University of Oxford), Norman Bishara (Ross School of Business, University of Michigan), David Hess (Ross School of Business, University of Michigan), Kevin Davis (New York University School of Law), Anita Ramasastry (University of Washington Law School), George Serafeim (Harvard Business School), Lucien Dhooge (Georgia Institute of Technology), Paul Carrington (Duke Law School), Richard Kauzlarich (Deputy Director, Terrorism, Transnational Crime and Corruption Center, George Mason University) and John de Figueiredo (The School of Law and the Fuqua School of Business, Duke University). Many thanks to all for their comments and suggestions. Special thanks also to Jonathan Darrow (Senior Research Consultant, Bentley University) for his research assistance. 
Is a bribe sometimes not a bribe? If facilitation payments are legal under United States law, why are companies prohibiting them? Who is a foreign official in a world where hospitals are often run by the state? Are all doctors then foreign officials? Can there be no drug company subsidization of conferences? In the context of the world economic slowdown, there is an increase in companies reporting that they are justified in paying money to win business. As pressures intensify on businesses and employees to secure contracts, the temptation is omnipresent during tough economic times to secure business by any means necessary. This paper will examine the dilemma posed by a goal of strict enforcement of anti-bribery legislation and its contradictions with some practical realities. We will review proposals to revise the FCPA and propose a more limited set of revisions.

\section{INTRODUCTION: THE DILEMMA}

The environment surrounding actual implementation of the antibribery requirements of regulations and codes around the world is in a state of flux. An especially difficult tension exists for any business conducting its affairs in the United States or in the United Kingdom today: it must navigate between the legal prohibitions on the corrupting influence of paying and accepting bribes and the practical recognition of both major regulatory schemes that, in certain cultures and situations, "facilitating payments" are absolutely necessary to ensure both personal safety and the safety of goods on the foreign dock or customs-house.

This paper seeks to explore the landscape of this business reality by examining the enforcement and compliance milieu thirty-plus years after the United States adopted the Foreign Corrupt Practices Act of 1977 (hereinafter the "FCPA"), ${ }^{1}$ but only a year after the United Kingdom followed suit in enacting a more draconian - at least on paper-statute, the United Kingdom Bribery Act (hereinafter the "UKBA"). ${ }^{2}$ We also consider

1. See Foreign Corrupt Practices Act of 1977, Pub. L. No. 95-213, 91 Stat. 1494 (codified as amended at 15 U.S.C. $\S \S 78 \mathrm{dd}-1 \& 78 \mathrm{dd}-2$ (2012)). The Act was amended by the Omnibus Trade and Competitiveness Act of 1988, Pub. L. No. 100-418, 102 Stat. 1107, and the International Anti-Bribery and Fair Competition Act of 1998, Pub. L. No. 105-306, 112 Stat. 3302. The FCPA was amended in 1988 by the Omnibus Trade and Competitiveness Act (OTCA), Pub. L. No. 100-418, $\S \S 5001-5003,102$ Stat. 1107, 14151425. The OTCA specifically amended 15 U.S.C. $\$ \S 78 \mathrm{~m}, 78 \mathrm{dd}-1,78 \mathrm{dd}-2$ (2012). For a discussion of the amendments, see Alan F. Holmer \& Judith H. Bello, The 1988 Trade Bill: Savior or Scourge of the International Trading System?, 23 INT'L LAW. 523 (1989) and Beverley H. Earle, Foreign Corrupt Practices Act Amendments: The Omnibus Trade and Competitiveness Act's Focus on Improving Investment Opportunities, 37 CLEV. ST. L. REV. 549 (1989) (discussing the importance to business of these changes).

2. The UK Bribery Act, 2010, c. 23, available at http://www.legislation.gov.uk/ukpga/ 2010/23. For an excellent summary, see generally Ivonne Mena King, Alexander J. Kramer \& Jacqueline N. Acosta, The US FCPA and the UK Bribery Act: Raising the Bar for Anti- 
the Organisation for Economic Co-operation and Development (hereinafter the "OECD"), whose pronouncements are increasingly influential in shaping the enforcement climate. ${ }^{3}$

In Part I, we briefly lay out the familiar contours of the FCPA as well as the relatively new framework of the UKBA. Both have explicit provisions relevant to this query and yet both reveal deep ambivalence about business reality, leaving the international business community to fend for itself in adopting compliance policies. The OECD's own suggested Guidelines have shifted in the past few years, further highlighting the depth of the international ambivalence.

In Part II, we focus on the dilemma posed by this state of affairs, asking questions any multinational business would ask while attempting to parse the statutory language surrounding "foreign officials," "facilitating payments," and the particular understanding of that grey area, "hospitality." Beyond examining terms, we examine the Department of Justice's (hereinafter the "DOJ") Opinion Releases to illustrate the US government's interpretation of this language as well as the United Kingdom's Guidance to Prosecutors, recently updated with language that highlights the dilemma under consideration here. On the business side, we consider how a representative sector of industry handles the question of when is a bribe not a bribe through a review of the pharmaceutical industry's self-regulatory efforts and the general policies of specific pharmaceutical companies. We conclude by attempting to paint a picture of bribery as the practical matter we believe it is currently understood to be.

Proposals for change that were the focus of 2011 legislative hearings in the United States as well as substantive revisions to the FCPA recently proposed by the United States Chamber of Commerce are the focus of Part III of this paper. We offer a critique of the proposals and our own modest proposal for change in Part IV.

\section{LEGAL CONTEXT: THE FCPA, THE UKBA AND THE OECD}

\section{A. The FCPA and the 1988 Amendments}

For two hundred years, the United States of America apparently did business in a similar way to the rest of the world, greasing palms held out by public officials and others in a position to make a deal go forward. In the 1970s, a Presidential resignation and a wave of legal and administrative investigations revealed a pattern and practice of US corporations bribing foreign officials. ${ }^{4}$ In particular, a 1976 scandal involving Lockheed Martin

Corruption Programs, 1949 PLI/CORP. 419 (2012).

3. The OECD formally criticized the FCPA's facilitation exception in 2010. See Robert N. Walton \& Michael L. Whitener, Our Own Backyard, FCPA BLoG (Nov. 1, 2010, 6:02 AM), http://www.fcpablog.com/blog/2010/11/1/our-own-backyard.html.

4. Michael V. Seitzinger, Foreign Corrupt Practices Act, CSR REPORT TO CONGRESS 
paying $\$ 1.4$ million to the Japanese Prime Minister to secure a contract for its L-1011 jet dominated the news. ${ }^{5}$ Soon, over 400 corporations admitted authorizing significant payments to foreign officials to secure lucrative contracts for their companies. ${ }^{6}$ To fix this perceived failure of business ethics, Congress enacted the FCPA ${ }^{7}$ which prohibited bribery and imposed accounting controls.

The FCPA focuses on conduct that offers something of "value" to "foreign public officials" in order to influence their official decisions, ${ }^{8}$ especially with respect to "obtaining or retaining business." The accounting provision, requiring accurate books and records, subjects an issuer to strict liability for inaccuracies of any sort; neither official knowledge nor materiality is required. ${ }^{10}$ A public entity may potentially be liable under the FCPA even if its officers were not aware of the inaccuracies, if they are considered immaterial and even if they do not include bribes; however, the Securities and Exchange Commission (SEC) has stated that without evidence of knowledge or reckless conduct, it will not seek prosecution ${ }^{11}$ Foreign issuers may be liable under the accounting

(Mar. 3, 1999). For a detailed description of the events leading up to the adoption of the FCPA, see Alejandro Posadas, Combating Corruption Under International Law, 10 DUKE J. COMP. \& INT'L L. 345 (2000).

5. See Lori Ann Wallin, The Gap Between Promise and Practice in the Global Fight Against Corruption, 6 ASPER REV. INT'L BUS. \& TRADE L. 209, 209-11 (2006). It is interesting to note that a similar fact pattern involving BAE bribes for Saudi purchases triggered the push for the Bribery Act recently enacted by the United Kingdom. See F. Joseph Warin, Charles Falconer \& Michael S. Diamant, The British Are Coming!: Britain Changes Its Law on Foreign Bribery and Joins the International Fight Against Corruption, 46 TEX. INT'L L.J. 1 (2010).

6. Foreign Corrupt Practices Act Antibribery Provisions, U.S. DEP'T of JUSTICE, http://www.justice.gov/criminal/fraud/fcpa/docs/lay-persons-guide.pdf (last visited Feb. 14, 2013) (discussing background of the FCPA).

7. See Foreign Corrupt Practices Act of 1977, Pub. L. No. 95-213, 91 Stat. 1494 (codified as amended at 15 U.S.C. $§ \S 78 d d-1 \& 78 \mathrm{dd}-2$ (2012)). The Act was amended by the Omnibus Trade and Competitiveness Act of 1988, Pub. L. No. 100-418, 102 Stat. 1107, and the International Anti-Bribery and Fair Competition Act of 1998, Pub. L. No. 105-306, 112 Stat. 3302.

8. 15 U.S.C. $\S 78$ dd-1(a), (f) (2012) (issuers); 15 U.S.C. $\S 78$ dd-2(a), (h)(2)(A) (2012) (domestic concerns); 15 U.S.C. $\S 78$ dd-3(a), (f)(2)(a) (2012) ("persons other than issuers and domestic concerns").

9. 15 U.S.C. $\S 78 \mathrm{dd}-1$ (a) (2012) (issuers); 15 U.S.C. $\S 78 \mathrm{dd}-2$ (a) (2012) (domestic concerns); 15 U.S.C. $\S 78 \mathrm{dd}-3$ (a) (2012) ("persons other than issuers and domestic concerns").

10. 15 U.S.C. $\S 78 \mathrm{~m}(\mathrm{~b})(2)$ (2012). See Andrea Dahms \& Nicolas Mitchell, Foreign Corrupt Practices Act, 44 AM. CRIM. L. REV. 605, 609-13 (2007) for a detailed outline of the current accounting requirements under the FCPA.

11. Justin F. Marceau, A Little Less Conversation, A Little More Action: Evaluating and Forecasting the Trend of More Frequent and Severe Prosecutions Under the Foreign Corrupt Practices Act, 12 FORDHAM J. CORP. \& Fin. L. 285, 298-300 (2007) (discussing agency law and the FCPA); Peter W. Schroth, The United States and the International Bribery Conventions, 50 AM. J. CoMP. L. 593, 601-04 (2002) (summarizing the effect of the 
provisions even if a corrupt payment occurs entirely outside the United States. The mere filing of a periodic report with the SEC or a single transaction with a U.S. bank is sufficient to trigger the obligations of the FCPA. $^{12}$

The inquiry is thus in three parts: What is value? Who is an official? And what does "obtaining or retaining business" mean? This section of the FCPA must also be read in the context of the modifications made in 1988 that allowed certain facilitating payments ${ }^{13}$ and recognized limited affirmative defenses, considered further below.

In its initial iteration, the FCPA staked out ground that proved far more than it could enforce or police. ${ }^{14}$ Congress later formally recognized that it might be necessary to facilitate or "grease" a transaction once a deal had been reached by amending the statute in 1988 to address certain realities of the marketplace. ${ }^{15}$ Accordingly, certain "facilitating payments" were carved out of the prohibitions of the FCPA, defined as "any facilitating or expediting payment to a foreign official, political party, or party official the purpose of which is to expedite or to secure the performance of a routine governmental action by a foreign official, political party, or party official." 16 (Emphasis added).

"Routine governmental action" is defined as:

[A]n action which is ordinarily and commonly performed by a foreign official in-

1988 amendments).

12. Oren Gleich \& Ryan Woodward, Foreign Corrupt Practices Act, 42 AM. CRIM. L. REV. 545 (2005) (summarizing the key features of the FCPA and analyzing its implementation); Foreign Corrupt Practices Act: An Overview, U.S. DEP'T OF JUSTICE, http://www.usdoj.gov/criminal/fraud/fcpa/ (last visited Feb. 15, 2013).

13. 15 U.S.C. $\S 78 \mathrm{dd}-1(\mathrm{f})(3)(B)$ (2012) (issuers); 15 U.S.C. $\S 78 \mathrm{dd}-2(\mathrm{~h})(4)$ (2012) (domestic concerns); 15 U.S.C. § 78dd-3(f)(4)(A) (2012) ("persons other than issuers and domestic concerns"). See also H.R. Rep. No. 100-579, at 921 (1988) (Conf. Rep.) (noting examples).

13. H.R. Rep. No. 100-418, at 921-23 (1988) (Conf. Rep.), reprinted in 1988 U.S.C.C.A.N. 1949, 1954-56. The conference agreement defined "lawful payment" as "a payment to a foreign official [that] is "lawful under the written laws and regulations of the foreign official's country." Id. at 1955.

14. See Jennifer Dawn Taylor, Ambiguities in the Foreign Corrupt Practices Act: Unnecessary Costs of Fighting Corruption?, 61 LA. L. Rev. 861, 869 n.57 (2001) (citing Robert S. Levy, Note, The Antibribery Provisions of the Foreign Corrupt Practices Act of 1977: Are They Really as Valuable as We Think They Are?, 10 DEL. J. CoRP. L. 71, 82 (1985)).

15. 15 U.S.C. § 78dd-1(b), -2(b), -3(b) (2012).

16. 15 U.S.C. $\S 78 \mathrm{dd}-1(\mathrm{f})(3)(\mathrm{A})(2012)$ (issuers); 15 U.S.C. $\S 78 \mathrm{dd}-2(\mathrm{~h})(4)(\mathrm{A})(2012)$ (domestic concerns); 15 U.S.C. $\S 78 \mathrm{dd}-3(\mathrm{f})(4)(\mathrm{A})$ (2012) ("persons other than issuers and domestic concerns") (emphasis added). See also Philip Nichols, Who Allows Facilitating Payments?, 14 AGORA WITHOUT FronTIERS 303 (2009) (Greece), available at http://idec.gr/iier/new/CORRUPTION\%20CONFERENCE/Nichols-facilitating-payments.pdf. 
(i) obtaining permits, licenses, or other official documents to qualify a person to do business in a foreign country;

(ii) processing governmental papers, such as visas and work orders;

(iii) providing police protection, mail pick-up and delivery, or scheduling inspections associated with contract performance or inspections related to transit across country;

(iv) providing phone service, power and water supply, loading and unloading cargo or protecting perishable products or commodities from deterioration; or

(v) actions of a similar nature. ${ }^{17}$

The affirmative defenses created by these amendments include allowing facilitation payments when there is proof that any payment made is lawful under the written laws and regulations of the local country. ${ }^{18}$ In reality, even in countries where graft is commonplace, it is not in fact legal. ${ }^{19}$

In addition, reasonable entertainment expenses -often referred to as hospitality expenses - may be allocated to foreign officials if proved to be a "bona fide expenditure[] such as travel and lodging ... related to ... promotion... of products... or execution or performance of a contract....,20 Intended to bring the FCPA into congruence with the principles adopted by the OECD, the 1998 amendments to the FCPA brought some foreign nationals under its jurisdiction ${ }^{21}$ and expanded its reach beyond US borders. ${ }^{22}$

Significantly, in order to qualify for the "facilitation payments"

17. 15 U.S.C. $\S 78 \mathrm{dd}-1(\mathrm{f})(3)(\mathrm{A})$

18. H.R. Rep. No. 100-418, at 921-23 (1988) (Conf. Rep.), reprinted in 1988 U.S.C.C.A.N. 1949, 1954-56. The conference agreement defined "lawful payment" as "a payment to a foreign official [that] is "lawful under the written laws and regulations of the foreign official's country." Id. at 1955.

19. Philip M. Nichols, The Business Case for Complying with Bribery Laws, 49 AM. Bus. L. J. 325, 352-67 (2012) (analyzing the depth and scope of local laws prohibiting bribery of domestic and foreign officials).

20. 15 U.S.C. $\S \S 78 d d-1(c)(2),-2(c)(2),-3(c)(2)$ (2012). This issue is the topic of two Department of Justice Opinion Procedure Releases discussed infra note 87 and accompanying text.

21. 15 U.S.C. $\S 78 d d-1(f)$ (2012). See Dahms \& Mitchell, supra note 10, at n.8 and accompanying text. See also supra note 4-6 for a comprehensive review of the events leading up to the adoption of both the FCPA and the OECD Convention.

22. 15 U.S.C. $\S 78 \mathrm{dd}-1(\mathrm{~g})$ (2012) (issuers); 15 U.S.C. $\S 78 \mathrm{dd}-2(\mathrm{i})$ (2012) (domestic concerns). 
exception, the expense must be accurately recorded to meet the FCPA's internal controls requirement. Obviously, then, a number of tensions are inherent in this provision for any business: determining whether the payment is a bribe or not; determining whether the host country laws permit the practice and, if they do not, recognizing that prosecution might result from the receiving end; and finally, the conundrum created by actually documenting payments in a fashion that will certainly invite scrutiny but will otherwise create criminal risk. Not surprisingly, then, the FCPA's exception for facilitation and reasonable entertainment expenses has been the subject of judicial discussion ${ }^{23}$ and academic analysis ${ }^{24}$ as the business world has attempted to weave it into everyday decision-making.

Indeed, this fact is in stark relief at the moment: the facilitation exception is likely to be a major legal issue in any government investigation into the recent allegations of bribery by Wal-Mart of Mexico. ${ }^{25}$ Indeed, it is possible that the Wal-Mart case will force serious discussion of the crux of the facilitation exception: if the political culture of a country requires certain payments from "all similarly situated businesses," then it is possible to argue that competition is not disrupted and that the payment is in fact a "routine government action." simple business reality in the host country, Mexico, currently in the throes of general chaos. One must wonder: does this characterization tend to remove the question from the judge and give it to the jury to decide as a question of fact ${ }^{27}$ or will it tend to move the government closer to repealing the facilitation payment exception? ${ }^{28}$

\section{B. OECD and Facilitation Payments}

All member countries and five non-member states adopted the OECD's landmark Convention on Combating Bribery of Foreign Public

23. United States v. Kay, 359 F.3d 738, 751 (5th Cir. 2004) ("[R]outine governmental action does not include the issuance of every official document or every inspection" but rather "very narrow categories of largely non-discretionary, ministerial activities performed by mid-or-low-level foreign functionaries.").

24. Joseph W. Yockey, Solicitation, Extortion, and the FCPA, 87 NOTRE DAME L. REV 781, 818-20 (2011). See also F. Joseph Warin et al., FCPA Compliance in China and the Gifts and Hospitality Challenge, 5 VA. L. \& BUs. REv. 33, $62-63$ (2010); Nichols, supra note 16.

25. David Barstow, Vast Mexico Bribery Case Hushed Up by Wal-Mart After Top-Level Struggle, N.Y. TimEs, Apr. 21, 2012, at A1, available at http://www.nytimes.com/2012/04/ 22/business/at-wal-mart-in-mexico-a-bribe-inquiry-silenced.html?_r=2.

26. Daniel Knight, Facilitation Payments: An Australian Perspective, FCPA BLOG (July 13, 2012, 8:02AM), http://www.fcpablog.com/blog/tag/facilitating-payments.

27. Id.

28. Elizabeth K. Spahn, Repeal the Facilitation Payment Loophole, FCPA Blog (Apr. 26, 2012, 1:28AM), http://www.fcpablog.com/blog/2012/4/26/repeal-the-facilitation-paymentloophole.html. 
Officials in International Business Transactions (hereinafter the "OECD Convention") ${ }^{29}$ in 1997 after years of discussion and debate. On a policy level, the OECD Convention was the first united effort to address corruption by the signatory countries. On a practical level, it set the precedent of prohibiting the common practice of deducting bribes as a business expense. ${ }^{30}$ All signatories now have adopted laws against corruption, even if enforcement is both cumbersome and inconsistent. ${ }^{31}$

Under the OECD Convention, signatories agree to regular, in-depth monitoring of efforts made to combat corruption. Interestingly, the first iteration of the OECD Convention did not prohibit facilitation payments and the associated Commentary to the Convention allows an exception for "small" facilitation payments, calling on member programs to support good governance initiatives but stating that "criminalisation ... does not seem a practical or effective complementary action." 32 Improper contributions and payments to foreign political parties and candidates were not discussed and neither was the extent to which bribery of family members of public officials should be considered corruption. ${ }^{33}$

The OECD regularly issues Guidelines as well as Recommendations to enhance its effort to combat corruption. ${ }^{34}$ Particularly, in November of 2009, the OECD issued its Recommendation for Further Combating Bribery of Foreign Public Officials (hereinafter, the "Recommendation"),

29. Convention on Combating Bribery of Foreign Public Officials in International Business Transactions, Dec. 18, 1997, 37 I.L.M. 1 [hereinafter OECD Anti-Bribery Convention]. For a list of the thirty-nine countries that are party to the OECD Anti-Bribery Convention, see OECD Convention on Combating Bribery of Foreign Public Officials in International Business Transactions: Ratification Status as of April 2012, OECD, http://www.oecd.org/corruption/oecdantibriberyconvention.htm (last visited Feb. 14, 2013).

30. Mark Pieth, Ten Years On: The Fight Against Foreign Bribery, OECD OBSERVER, May 2010, http://www.oecdobserver.org/news/fullstory.php/aid/3253/Ten_years_on:_The_fight_ against_foreign_bribery.html.

31. Fighting Bribery in International Business Deals, OECD POLICY BRIEF, Sept. 2008, at 4-6 (describing the enforcement mechanism), http://www.oecd.org/dataoecd/55/44/ 41360706.pdf; see also Pieth, supra note 30 (noting that although the enforcement mechanism is "the gold standard," it is not uniform).

32. OECD Anti-Bribery Convention, supra note 29, at Commentary Art.1, If 9. Commentaries to the Convention were adopted by the Negotiating Conference on November 21, 1997. See Jon Jordan, The OECD's Call for an End to "Corrosive" Facilitation Payments and the International Focus on the Facilitation Payments Exception Under the Foreign Corrupt Practices Act, 13 U. PA. J. Bus. L. 881, 896-903 (2011).

33. Posadas, supra note 4, at 381 (footnotes omitted).

34. For example, in May of 2006, the OECD adopted guidelines requiring companies seeking export guarantees from first world governments to declare whether any of their staff had been charged with or convicted of bribing foreign officials. These guarantees, worth approximately $\$ 60$ billion per year, were viewed as a significant factor in closing large projects, but were often given without any inquiry into the "clean hands" of the recipient. Michael Peel \& Hugh Williamson, OECD Says Companies Must Reveal Record on Bribery, Fin. Times, May 16, 2006, at 8. 
calling on thirty-eight State Parties to the OECD Convention to attend to the roles of agents and third-party intermediaries and to "periodically review policies and approach on small facilitation payments. $" 35$ In 2010 , the OECD Working Group on Bribery, the committee group in charge of the monitoring process, took the United States to task with its recommendation during Phase 3 evaluations of the record on anti-corruption efforts, specifically suggesting "further attention [to] policies on and approach to facilitation payments ...."36 In taking this position, the OECD mirrored the approach taken by most US corporations, $87 \%$ of which prohibit facilitation payments as a matter of internal policy. ${ }^{37}$

Important to our discussion to follow, the Good Practice Guidance on Internal Controls, Ethics and Compliance, Annex II of the Recommendations and adopted by the OECD in 2010, suggests a number of "good practices for ensuring effective internal controls, ethics and compliance programmes or measures for the purpose of detecting or preventing bribery," including specifically recommending that "business organizations ... play a leading role in providing anti-bribery information, advice and training to companies, especially small- and medium-sized enterprises." ${ }^{38}$ Areas of specific concern include the following familiar list which is, "applicable to all directors, officers, and employees, and applicable to all entities over which a company has effective control, including subsidiaries, on, inter alia, the following areas:

i) gifts;

ii) hospitality, entertainment and expenses;

iii) customer travel;

iv) political contributions;

v) charitable donations and sponsorships;

vi) facilitation payments; and

vii) solicitation and extortion ....."39

This list illustrates shared concerns, but does not offer much more

35. Government Agrees to Step Up Fight Against Bribery, OECD, Sept. 12, 2009, http://www.oecd.org/document/34/0,3746,en_21571361_44315115_44232739_1_1_1_1,00. html.

36. Annual Report, OECD WORKING GROUP ON BRIBERY (2010), at 23, http://www.oecd.org/dataoecd/7/15/47628703.pdf [hereinafter OECD WORKING GROUP ON BRIBERY].

37. Global Anti-Bribery and Corruption Survey 2011, KPMG, 2011, at 17, http://www.kpmg.com/UK/en/IssuesAndInsights/ArticlesPublications/Documents/PDF/Advisory/ 23816NSS_Global_ABC_Survey.PDF; OECD Calls for End to Facilitating Payments Exception, JONES DAY, Dec. 2009, http://www.jonesday.com/oecd_calls/ (placing the figure at $80 \%$ ).

38. OECD WORKING GROUP ON BRIBERY, supra note 36 , at 63 \& 13.

39. Id. at 63-64. 
information. Although the OECD makes efforts to monitor developments in its member countries regarding these business-related expenses, research reveals little evidence of any meaningful implementation of policies targeting these concerns. Indeed, although fifteen of the G20 members are party to and have implemented the OECD's Convention and in doing so have committed to strengthening legal and other measures to combat bribery, ${ }^{40}$ little evidence of any public movement by either OECD or G20 member states is available. ${ }^{41}$ Although the OECD purports to publish information about the civil, criminal, and administrative efforts made by their member states, the data made public is in gross terms by country. ${ }^{42}$

\section{The United Kingdom Bribery Act}

International business attention is now firmly focused on the UKBA as this law, enacted in 2010 and in effect since July 1, 2011, quite radically ups the ante of the FCPA in several respects. ${ }^{43} \mathrm{~A}$ document issued by the United Kingdom Ministry of Justice titled, "The Bribery Act of 2010: Guidance" (hereinafter, the "Guidance") offers guidance to the business aspects of the new statute. The Forward to this document catches one's attention, as it is intended to do:

Bribery blights lives. Its immediate victims include firms that lose out unfairly. The wider victims are government and society, undermined by a weakened rule of law and damaged social and economic development. At stake is the principle of free and fair competition, which stands diminished by each bribe offered or accepted. ${ }^{44}$

Partly in response to a government scandal involving the paying of bribes by BAE Systems, the United Kingdom has crafted what some

40. First Monitoring Report of the G20 Anti-Corruption Working Group to G20 Leaders on Individual and Collective Progress Made by G20 Countries in the Implementation of the Seoul Action Plan, OECD, 2011, at 2, http://www.oecd.org/dataoecd/19/32/49234763.pdf.

41. Transparency International recently issued a report critical of OECD and G20 enforcement efforts in these areas, suggesting they are "standing still," Standing Still? What the World's Biggest Economies Are Doing About Corruption, TranSPARENCY INT'L, Apr. 5, 2012,

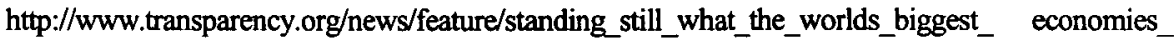
are_doing_about_corruption.

42. 2010 Data on Enforcement of the Anti-Bribery Convention, OECD WORKING GROUP ON BRIBERY, Apr. 2011, http://www.oecd.org/dataoecd/47/39/47637707.pdf.

43. See infra note 45.

44. The Bribery Act 2010: Guidance, MinistRY Of Justice (U.K.), at 2, Mar. 2011, http://www.justice.gov.uk/downloads/legislation/bribery-act-2010-guidance.pdf. [hereinafter Bribery Act 2010: Guidance] 
international businesses view as a "draconian" law ${ }^{45}$ that is now a benchmark of international understanding of improper bribery.

The basic framework of the UKBA is rather straightforward and addresses four main areas of criminal liability: (1) active bribery, which is defined to mean "offering, promising or giving a bribe in exchange for improper performance of a function or activity"; (2) passive bribery, which includes "requesting, agreeing to receive or accepting a bribe" in the same context; (3) the familiar "bribing a foreign public official"; and (4) the much discussed "corporate offence" with its "adequate procedures defense. ${ }^{, 46}$ Oddly, the UKBA does not exactly define the term "bribe, ${ }^{, 47}$ a conundrum we will consider in Part II of this paper.

The UKBA does add certain elements to the international enforcement arena that are beyond the scope of the FCPA. Most critical is the specific criminalization of both private bribery and the activity of agents and external third parties who "perform business" on behalf of a business entity, not "simply" provide it with supplies. ${ }^{48}$ Of specific importance is the fact that any party that does business in the United Kingdom is subject to the law, whether or not the improper "function or activity" in question has any connection to the United Kingdom. ${ }^{49}$

Further explaining the contours of the new law, the United Kingdom Ministry of Justice Guidance provides some insight into the government's enforcement agenda. Two elements apply here: (1) the explanation of prohibited entertainment and (2) gifts and the government's understanding of facilitation payments. Both elements seem to be less a matter of strict application of the statute and more a matter of prosecutorial discretion. With respect to the former, the touchstone will be "reasonable and proportionate" in light of industry norms, legitimate business needs, and transparency. ${ }^{50}$ As to the latter, the subject of Part II of this paper, the

45. Saleha Way, UK Faces a Dilemma over Its Proposed Draconian Bribery Legislation, Feb. 22, 2011, THENATIONAL, http:/www.thenational.ae/thenationalconversation/industry-insights/ economics/uk-faces-a-dilemma-over-its-proposed-draconian-bribery-legislation (Bribery Act "lumbers business" by criminalizing certain business behavior even acceptable under the FCPA, especially facilitation payments); See also Nigel Page ed., Serious Economic Crime: A Boardroom Guide to Prevention and Compliance, SERIOUS FraUd OfFICE (U.K.), 2011, http://www.seriouseconomiccrime.com/ebooks/Serious-Economic-Crime.pdf.

46. The U.K. Bribery Act, 2010, c.23, $\$ 7$ \& 13. See also UK Bribery Act: Current Enforcement Trends, BINGHAM MCCUTCHEN LLP, at 2, Mar. 2012, http://www.bingham.com/ Publications/Files/2012/03/Thought-Piece-UK-Bribery-Act-Current-Enforcement-Trends [hereinafter Current Enforcement Trends].

47. Current Enforcement Trends, supra note 46, at 2.

48. The Bribery Act, Quick Start Guide, MINISTRY OF JUSTICE (U.K.), at 2-3, $\mathrm{http} / / \mathrm{www}$.justice.gov.uk/downloads/legislation/bribery-act-2010-quick-start-guide.pdf (last visited Feb. 14, 2013).

49. Current Enforcement Trends, supra note 46, at 4

50. See also Current Enforcement Trends, supra note 46, at 3-4. [note possible OECD criticism to this more relaxed approach.] 
Guidance perhaps raises more questions than it answers.

On the one hand, it indicates that the Government does not intend to pursue corporate facilitation payments that are proper under the written law of the host country. ${ }^{51}$ But at the same time, there is an explicit declaration that the elimination of such payments is a "long term objective" of the UKBA and a clear nod to prosecutorial discretion in each case. ${ }^{52}$ This might be influenced by two important factors:

a proactive approach involving self-reporting and remedial action ... and a clear and appropriate policy setting out procedures to be followed if facilitation payments are requested, accompanied by adherence to such policies. This reinforces the importance of an effective compliance programme, since policies and procedures, and a culture of internal reporting, will weigh against prosecution. ${ }^{53}$

As in the United States, enforcement elements of the UKBA are being developed in real time. On May 17, 2012, the United Kingdom Ministry of Justice announced a proposal to adopt deferred prosecution agreements not currently part of the enforcement landscape and invited comments until August 9, 2012. ${ }^{54}$ Unlike the process in the United States where the company negotiates with the DOJ, the United Kingdom proposes that an independent judge would supervise the agreement to ensure that it is "fair, in the public interest and that the conditions properly reflect the nature of the wrongdoing including reparations made to victims." 55

\section{EXAMINING REGULATORY AMBIVALENCE: STATUTORY INTERPRETATIONS VERSUS BUSINESS REALITY}

\section{A. Penalties and Individual Prosecutions under the FCPA}

The FCPA provides for both civil and criminal penalties for violation of either its anti-bribery or accounting requirements. ${ }^{56}$ Prior to 2000 , few

51. Bribery Act 2010: Guidance, supra note 44.

52. Id.

53. Current Enforcement Trends, supra note 46, at 4.

54. Deferred Prosecution Agreements: Overview, MINISTRY OF JUSTICE (U.K.), https://consult.justice.gov.uk/digital-communications/deferred-prosecution-agreements (last visited Feb. 13, 2013).

55. Barry Vitou \& Richard Kovalevsky, Ministry of Justice Publishes Deferred Prosecution Agreement Consultation, THEBRIBERYACT.COM (May 17, 2012), http:/thebriberyact.com/2012/ 05/17/breaking-ministry-of-justice-publishes-deferred-prosecution-agreement-consultation/.

56. Civil penalties for the former include up to $\$ 10,000$ per violation for both corporate and individual defendant; criminal fines may be up to $\$ 2$ million per violation for corporations and up to $\$ 100,000$ per violation and prison time of up to five years for 
reported cases and relatively light fines characterized the enforcement of the statute. ${ }^{57}$ Between 1995 and 2000, the DOJ averaged less than one completed investigation per year. ${ }^{58}$ The climate dramatically changed almost overnight, ${ }^{59}$ resulting in enormous liability for companies not able or willing to detect the change in the air. For example, in 2008, Siemens, a German conglomerate, paid over a billion dollars in fines $(\$ 450$ million to the DOJ, \$350 million to the SEC for related charges, and \$533.6 million to European authorities) to settle charges for their agents travelling regularly to South America and elsewhere with suitcases of cash to further their business interests. ${ }^{60}$ The next year, Halliburton and Kellogg Brown and Root, LLC (KBR) also settled FCPA charges for a $\$ 402$ million fine. ${ }^{61}$ Further, in 2010, BAE Systems pled guilty to, among other things, conspiring to "make false statements about its Foreign Corrupt Practices

individuals. Failure to comply with the accounting requirements may result in criminal penalties of up to $\$ 25$ million for the corporation and individuals may face fines of up to $\$ 5$ million and 20 years in jail. See 15 U.S.C. $\$ \S 78 \mathrm{dd}-3$ (d)-(e), 78ff (2012) (outlining penalties for violations of the FCPA).

57. Charlie Savage, With Wal-Mart Claims, Greater Attention on a Law, N.Y. TimES (Apr. 25, 2012), http://www.nytimes.com/2012/04/26/business/global/with-wal-mart-briberycase-more-attention-on-a-law.html ("It always had teeth .... The United States government was just never interested in biting," quoting Professor Rachel Brewster of Harvard University). See Marceau, supra note 11, at 290-95 (discussing the U.S. Department of Justice's increased vigor in recent FCPA prosecutions); Philip Segal, Coming Clean on Dirty Dealing: Time for a Fact-Based Evaluation of the Foreign Corrupt Practices Act, 18 FLA.J. INT'L L. 169 (2006) (surveying all reported FCPA enforcement actions and concluding that the FCPA has been "greatly under-enforced"). See also Steven Salbu, Bribery in the Global Market: A Critical Analysis of the Foreign Corrupt Practices Act, 54 WASH. \& LEE L. Rev. 229, 231-32 (arguing, generally, that the FCPA ignores cultural norms of gift-giving and is overly intrusive).

58. Patti Waldmeir, Bribery Is Not Just a Cost of Doing Business, FN. TIMEs, April 5, 2007.

59. See Transcript of Press Conference Announcing Siemens AG and Three Subsidiaries Pled Guilty to Foreign Corrupt Practices Act Violations, U.S. DEP'T OF JUSTICE (Dec. 15, 2008), http://www.justice.gov/opa/pr/2008/December/08-opa-1112.html ("From 2001 to 2004, the Department [of Justice] resolved or charged 17 FCPA cases. For the period 2005 to 2008, that number [was] 42 resolutions, representing an increase of more than 200 percent ... compared to the prior four-year period."). In late 2009, Assistant Attorney General Lanny A. Breuer announced, "Since 2005, we have brought 57 cases-more than the number of prosecutions brought in the almost 30 years between the enactment of the FCPA in 1977 and 2005." Lanny A. Breuer, Prepared Keynote Address to the Tenth Annual Pharmaceutical Regulatory and Compliance Congress and Best Practices Forum, Nov. 12, 2009, http://www.ehcca.com/presentations/pharmacongress 10/breuer_2.pdf.

60. Siemens $A G$ and Three Subsidiaries Plead Guilty to Foreign Corrupt Practices Act Violations and Agree to Pay $\$ 450$ Million in Combined Criminal Fines, U.S. DEP'T OF JUSTICE (Dec. 15, 2008), http://www.justice.gov/opa/pr/2008/December/08-crm-1105.html ("[B]ribery was nothing less than standard operating procedure for Siemens.").

61. Kellogg Brown \& Root LLC Pleads Guilty to Foreign Bribery Charges and Agrees to Pay \$402 Million Criminal Fine, U.S. DEP'T OF JUSTICE (Feb. 11, 2009), http://www.justice.gov/opa/pr/2009/February/09-crm-112.html. 
Act compliance program....,62 Despite the DOJ's efforts in heightening corporate awareness of the commands of the FCPA with large fines, it decided that "to have a credible deterrent effect, people have to go to jail.",63 Individual prosecutions increased "from six in 2006 to 48 in 2010."

Ironically, the DOJ has lost much credibility through this initiative as only one of its individual prosecutions has resulted in a conviction ${ }^{65}$ and many were dismissed due to prosecutorial misconduct. ${ }^{66}$ In particular, the

62. BAE Systems PLC Pleads Guilty and Ordered to Pay $\$ 400$ Million Criminal Fine, U.S. DEP'T OF JUSTICE, Mar. 1, 2010, http://www.justice.gov/opa/pr/2010/March/10-crm209.html.

63. Alberto Gonzalez, Richard Westling \& William Athanas, Forecasting the Future of FCPA Enforcement, CORPORATE COUNSEL (May 9, 2012), available at http://www.law.com/ jsp/cc/PubArticleFriendlyCC.jsp?id=1202552821910 (quoting Mendelsohn Says Criminal Bribery Prosecutions Doubled in 2007, 22 CORPORATE CRIME REPORTER 36 (2008)). See also Record Setting: Esquenazi Sentenced to 15 Years, Rodriguez to 7 Years, FCPA PROFESSOR (Oct. 26, 2011), http://www.fcpaprofessor.com/record-setting-esquenazi-sentenced-to15-years-rodriguez-to-7-years [hereinafter Record Setting]

Yesterday, in the Southern District of Florida (a district quickly earning the distinction of handing out the toughest FCPA sentences in the country ... Judge Jose Martinez sentenced Joel Esquenazi to a recordsetting 15 years .... and co-defendant Carlos Rodriguez to 7 years.... The previous record for an FCPA sentence was in April 2010 when Charles Jumet was sentenced to a then record 7.25 years (67 months on an FCPA charge, 20 months on a false statement charge). In the DOJ's release... Assistant Attorney General Lanny Breuer stated as follows. 'This sentence - the longest sentence ever imposed in an FCPA case - is a stark reminder to executives that bribing government officials to secure business advantages is a serious crime with serious consequences. A company's profits should be driven by the quality of its goods and services, and not by its ability and willingness to pay bribes to corrupt officials to get business. As today's sentence shows, we will continue to hold accountable individuals and companies who engage in such corruption.' Esquenazi and Rodriguez were two of the defendants in the so-called Haiti Teleco case, the largest FCPA enforcement action in history (minus the manufactured Africa Sting case) in terms of individual defendants - 12. As noted in [a] prior post, the Haiti Teleco case stands in stark contrast to many corporate FCPA enforcement actions (enforcement actions that sometimes involve tens or hundreds of millions of dollars in bribe payments) that often yield no individual enforcement actions. Indeed, as noted in [another] prior post, since 2008 approximately $70 \%$ of corporate DOJ FCPA enforcement actions have not (at least yet) resulted in any DOJ charges

Id. against company employees.

64. Alberto Gonzalez, Richard Westling \& William Athanas, Forecasting the Future of FCPA Enforcement, CORPORATE COUNSEL, May 9, 2012, available at http://www.law.com/ jsp/cc/PubArticleFriendlyCC.jsp?id=1202552821910.

65. See Record Setting, supra note 63.

66. Roger M. Witten, The Foreign Corrupt Practices Act and International Anti- 
"African Sting" cases and the Lindsey Manufacturing case stand as examples of what one judge ruefully called, "a long and sad chapter" in the government's enforcement history. ${ }^{6}$

Quite obviously, until recently, most individuals and corporations have chosen to plea bargain rather than risk trial in FCPA cases. Consequently, the interpretation of what these words mean has been left to the expansive view of the DOJ and not otherwise challenged. ${ }^{68}$ As of 2012, the legal landscape in FCPA has shifted as parties have risked trial and have prevailed, although perhaps not exactly on the merits of the actual charge.

One must also understand that many companies flatly prohibit facilitating payments despite the law's acceptance of them. ${ }^{69} \mathrm{~A}$ facilitating payment is distinguished from a bribe because it is not to secure the business and it is not "corruptly" offered. However, this line is not always clear.

\section{B. The UKBA}

\section{Facilitation Payments}

Effective July 2011, the UKBA purports to limit facilitating payments but it remains to be seen how this will be enforced given the lack of allocated resources. More importantly, the Joint Prosecution Guidance of the Director of the Serious Fraud Office and the Director of Public Prosecutions lists "Public Interest Considerations" that should be taken into account before the prosecutors initiate any action. These considerations also make special mention of facilitation payments, noting: "There is no exemption in respect of facilitation payments. They were illegal under the

Corruption Developments, 1949 PLI/CORP 89 (2012) (discussing United States v. Noriega, No. 2:10-cr-01031-AHM (C.D. Cal. Feb. 28, 2011) ("Lindsey Manufacturing" case), United States v. Carson, No. 8:09-cr-00077-JVS (C.D. Cal. Feb. 21, 2011) and United States v. O'Shea, No. 4:09-cr-00629 (S.D. Tex. Jan. 3, 2012)); Paul T. Friedman \& Demme Doufekias, United States: Most Severe Setback to DOJ Thus Far in FCPA Prosecutions: Judge Dismisses All Charges in Africa Sting Case, MORRISON \& FOERSTER (Mar. 1, 2012), http://www.mondaq.com/unitedstates/x/166392/White+Collar+Crime+Fraud/Most+Severe+ Setback+To+DOJ+Thus+Far+In+FCPA+Prosecutions+Judge+Dismisses+All+Charges+In+ Africa+Sting+Case.

67. Friedman \& Doufekias, supra note 66.

68. Cf. Michael B. Mukasey \& James C. Dunlop, Can Someone Please Turn on the Lights? Bringing Transparency to the Foreign Corrupt Practices Act, 13(1) ENGAGE 31 (2012), available at http://www.fed-soc.org/publications/detail/can-someone-please-turn-onthe-lights-bringing-transparency-to-the-foreign-corrupt-practices-act.

69. Deloitte Anti-Corruption Practices Survey 2011: Cloudy with a Chance of Prosecution?, 1957 PLI/CORP 559, 567 (2012) ("[A]lmost half of the executives said their company prohibited facilitating payments in all cases. ... For the remaining executives, 36 percent said facilitating payments were allowed with pre-approval . . ...) [hereinafter Cloudy with a Chance of Prosecution?]. 
previous legislation and the common law and remain so under the Act." ${ }^{, 70}$ Despite this ban on such payment, the document outlines "[f]actors tending against prosecution" under the following circumstances:

- A single small payment likely to result in only a nominal penalty ...;

- The payment(s) came to light as a result of a genuinely proactive approach involving self-reporting and remedial action...;

- Where a commercial organization has a clear and appropriate policy setting out procedures an individual should follow if facilitation payments are requested and these have been correctly followed;

- the payer was in a vulnerable position arising from the circumstances in which the payment was demanded. ${ }^{71}$

The tension is evident: the United Kingdom appears to take a very strict position in not allowing facilitation payments, but the Guidance is quite relaxed in terms of which cases the government might choose to bring. In particular, it appears that if a company has a policy about how to deal with this problem and reports it, then the prosecutors would not proceed. Similarly, the last factor noted above recognizes that a person could be in a "vulnerable position" and thus believe they have no choice but to pay. This statement is quite broad and undefined. ${ }^{72}$

If you were asked to pay to protect your employees, would you? This was precisely the dilemma faced by Chiquita Brands International and its executives, including one who was both a distinguished attorney and former Chairman of the SEC. ${ }^{73}$ Yet could you find yourself in legal difficulty? Yes. The DOJ reportedly gave "serious consideration to filing such charges after the company had pleaded guilty and paid a $\$ 25$ million fine for making protection payments to a right wing militia in Colombia, in violation of United States law"74 (but not the FCPA). "In an exercise of

70. Bribery Act 2010: Joint Prosecution Guidance of the Director of the Serious Fraud Office and the Director of Public Prosecutions, Serious Fraud Office (U.K.), at 9, www.sfo.gov.uk/media/167348/bribery_act_2010_joint_prosecution_guidance_of_the_director of_the_serious_fraud_office_and the_director_of_public_prosecutions.pdf (last visited Feb. 13, 2013) [hereinafter Joint Prosecution Guidance].

71. Id.

72. For a discussion of the problems with broad and undefined statements, see Dershowitz, infra note 142 and accompanying text.

73. Heidi White et al., Chiquita and the Department of Justice, INSTITUTE FOR CORPORATE ETHICS (Feb. 2, 2012), http://www.corporate-ethics.org/pdf/case_studies/BRI1008_Chiquita_and_Department_of_Justice.pdf.

74. Neil A. Lewis, No Charges for Chiquita Executives, N.Y. TimEs (Sept. 13, 2007), http://query.nytimes.com/gst/fullpage.html?res=9C0CE4DA1731F930A2575AC0A9619C8. 
prosecutorial discretion," the DOJ elected not to file charges. ${ }^{75}$ If your product were in danger of being stolen from a dock or if there could be some other potential harm to you or to your product, you could make the payment under the Guidance but you would be obligated to report it. US businesses have been asking for this common sense recognition of other factors that go into a calculus of whether to bring charges against companies that make facilitation payments.

\section{Hospitality and Promotional Expenditures}

As noted above, in assessing whether hospitality and promotion expenses are legal under the UKBA, British enforcement authorities suggest they will use notions of common sense: Are expenditures "reasonable and proportionate" or "lavish and extravagant.," M6 More specifically, they will determine:

whether there is evidence that the payment is to induce someone to improperly perform their duties with a view to obtaining a business advantage. A payment may be looked at as a bribe if it is related in time to some actual or anticipated business with the recipient, particularly where some form of competitive process is involved. This has been coined the "improper performance test."

In April 2012, a new Director of the SFO, David Green, brought with him a new approach to enforcement, perhaps responding to certain criticism regarding a more relaxed approach than the international comnunity expected. $^{78}$

The Guidance also addresses "hospitality and promotional expenditures." Expenditures must be "reasonable, proportionate and made

75. Id.

76. Bribery Act of 2010: Guidance, supra note 44, at 12.

77. Nicole Sprinzen, Litigation: It's the Little Things that Make a Difference, INSIDE CoUNSEL (June 7, 2012), http://www.insidecounsel.com/2012/06/07/litigation-its-the-littlethings-that-make-a-diffe?page $=4$. quoting British Bankers' Association, Bribery Act 2010, Practical Implementation Issues For the Banking Sector, Dec. 2011, at 36, http://bba.org.UK/ media/article/bribery-act-2010-guidance.

78. "[T]he Organization for Economic Cooperation and Development (OECD) in its Working Group Phase 3 Report on Implementing the OECD Anti-Bribery Convention under the Bribery Act [criticized the SFO] for its practice of attempting to settle cases civilly wherever possible, and particularly in cases where a company self-reports misconduct." Sprinzen, supra note 77. Director David Green aspires to address "the perception [that] has emerged over the last few years that perhaps there is more willingness to compromise than to prosecute." Id., quoting Caroline Binham, New SFO Director Pledges Tougher Stance, FIN. TIMES (U.K.), Apr. 26, 2012, http://www.ft.com/cms/s/0/6d8b01de-8fa0-1 le1-98b1-00144feab49a.html. 
in good faith ....,79 The inquiry becomes: was there an element of trying to influence the official? The SFO sees a correlation between lavishness and impropriety, but the Guidance notes that lavishness is "just one factor" and "other factors might include that the hospitality or expenditure was not clearly connected with legitimate business activity or concealed." example, the Guidance suggests that taking clients to a match "designed to cement good relations or enhance knowledge in the organisation's field" [sic] would not show an intent to bribe. ${ }^{81}$ Nor would an offer to transport a foreign official to see your hospital in another country or a "fine dining" experience and baseball game which were part of a visit to your factory be suspect, whereas a vacation at a five star resort would raise an "inference" of illegal activity. ${ }^{82}$

\section{DOJ Opinion Releases}

When does a "facilitation payment" cross the line and become a bribe? Is it based on the intent? What is value? When does paying for travel and promotion expenses amount to a bribe? Is it a matter of lavishness? Is there a bright line between how much and how little? The answer is clearly no--the line is anything but clear.

Although US prosecutors suggest they have never gone after de minimis cases, ${ }^{83}$ this is not of great comfort or a guarantor of certainty to business people. Neither does the existence of a DOJ "Opinion Procedure Release" comfort companies trying to do business in this environment. Since 1980, more than half of the fifty-six DOJ's Opinion Releases have addressed either the problem of dealing with a foreign official or travel and promotion expenses. ${ }^{84}$ Specifically, twenty-one Opinion Releases have looked at the issue of "foreign official" (either doing business with one or a relative of one) and thirteen have addressed travel and promotion

79. Joint Prosecution Guidance, supra note 70, at 10.

80. Id.

81. Id. at 10 .

82. Id. at 14. But see Roger M. Witten, Anti-Corruption Enforcement Developments: 2011 Year in Review and 2012 Preview, 1949 PLI/CORP 89, 98 (2012) (discussing a 2011 IBM settlement of $\$ 10$ million for over 100 instances of problems with IBM-China's entertainment practices and a 2011 settlement with AON for $\$ 16.26$ related to the entertainment of third parties in Egypt, Vietnam, Indonesia, United Arab Emirates, Myanmar, Bangladesh and Costa Rica.).

83. Foreign Corrupt Practices Act: Hearing Before the Subcommittee on Crime, Terrorism and Homeland Security of the Committee on the Judiciary of the House of Representatives, 112 Cong. 56 (2011) (statement of Greg Andres, Deputy Assistant Att'y Gen., Criminal Division, U.S. Dep't of Justice).

84. See infra notes 91-92 (Figure 1 - DOJ FCPA Opinion Procedure Releases, p. 24; Table 1 - Inventory of Opinion Releases, pp. 25-27.) 
expenses. ${ }^{85}$ The term "foreign official" is used broadly and yet many of the Opinion Releases give preliminary approval of the described arrangement despite the fact that the person is a foreign official. ${ }^{86}$ While several of the Opinion Releases have included specific dollar figures, the majority have been approved with an unspecified dollar amount. At least one Opinion Release approved a spouse's travel expense. ${ }^{87}$ Four involved gifts and three addressed the donation to a charity (including a large $\$ 10$ million dollar outlay for a medical facility). ${ }^{88}$ Many of the Opinion Releases involving the issue of foreign officials seek waivers and permission to pay a governmental official, but try to clarify that it is not to secure a contract or, in several cases, that the payment is required by law. ${ }^{89}$ Of the thirteen that involved travel and promotion, only four disclosed a specific dollar amount and only two identified the payor, but seven identified the nationality of the recipient. ${ }^{90}$ Although the fifty-six Opinion Releases in thirty-two years shows that counsels are not rushing to use this mechanism, one can conclude that certain ambiguity in the law exists in two particular areasforeign official and travel/promotion expense--that if clarified would help all legitimate businesses trying to abide by the law.

85. Opinion Procedure Releases, U.S. DEP'T OF JUSTICE, http://www.justice.gov/ criminal/fraud/fcpa/opinion (1993-2001) (last visited Feb. 13, 2013); Review Procedure Releases, U.S. DEP'T OF JUSTICE, http://www.justice.gov/criminal/fraud/fcpa/review (19801992) (last visited Feb. 13, 2013).

86. See supra note 85. See also infra Table 1 - Inventory of Opinion Releases pp. 25-27, which lists twenty-one opinions dealing with the term "foreign official." But see Eleventh Circuit Asked to Define "Foreign Official" Under FCPA, AM. LaW. LiTIG. DaILY (May 15, 2012), available at http://www.law.com/jsp/cc/PubArticleFriendlyCC.jsp?id=1202553419587 (discussing appellate brief filed for Rodriguez and Esquenazi who are appealing their 2011 sentences and arguing that the "act does not support an expansive interpretation of "instrumentality"' and thus the people were not foreign officials).

87. Review Procedure Releases, U.S. DEP'T OF JUSTICE, No. 83-02, July 26, 1983, available at http://www.justice.gov/criminal/fraud/fcpa/review/1983/r8302.pdf.

88. See infra notes $91-92$

89. See, e.g., Opinion Procedure Release, U.S. DEP'T OF JUSTTCE, No. 07-03, Dec. 21, 2007, http://www.justice.gov/criminal/fraud/fcpa/opinion/2007/0703.pdf; Review Procedure Releases, U.S. DEP'T OF JUSTICE, No. 88-01, May 12, 1988, available at http://www.justice.gov/ criminal/fraud/fcpa/review/1988/r8801.pdf.

90. See infra note 92 . 


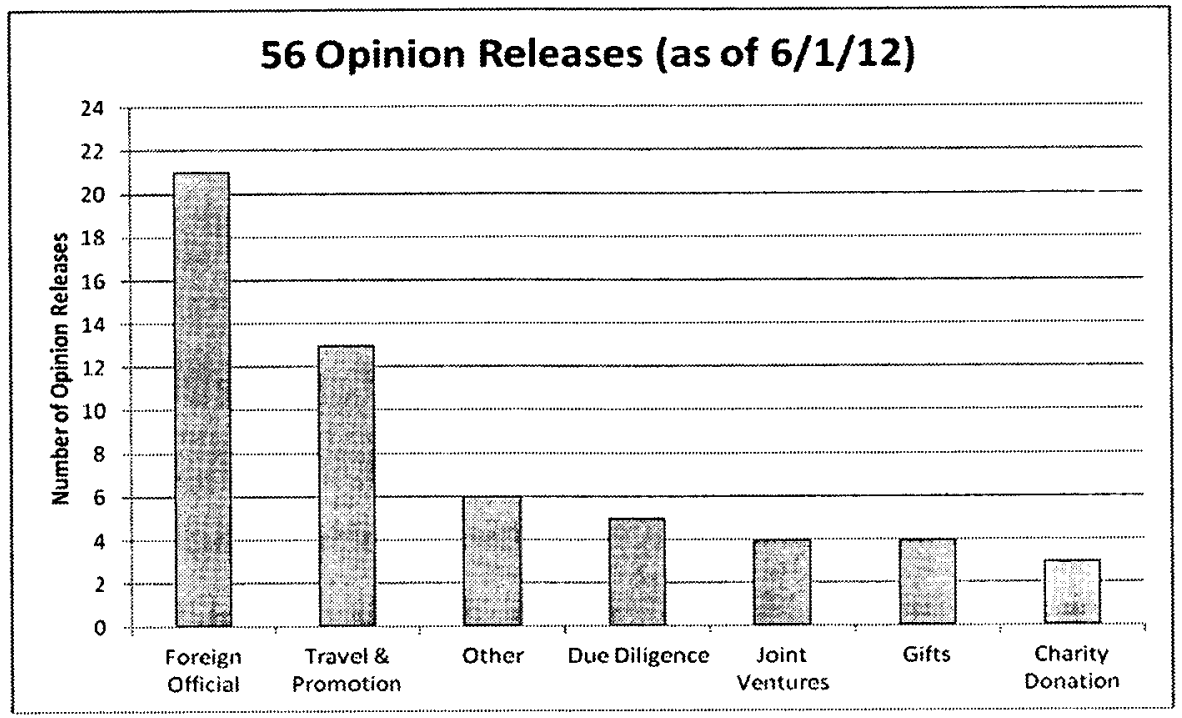

Figure 1 - DOJ FCPA Opinion Procedure Releases ${ }^{91}$

Table 1 - Inventory of Opinion Releases ${ }^{92}$

56 as of $6 / 1 / 12$

\section{Foreign Official (FO) (21 items)}

$10-03$ (consultant is foreign agent)

10-01 (required by contract to hire FO)

07-03 (payment to judge required for processing of an estate)

06-02 (subsidiary hires foreign law firm, do not know if FO; paid $0.6 \%$ of foreign exchange)

01-02 (American and foreign company enter into consortium, foreign company's chairman is FO)

00-01 (law firm partner is FO)

96-02 (American company hires state owned enterprise (SOE) as marketing representative)

95-03 (relative of FO)

94-01 (subsidiary enters into contract with director of SOE for

91. Figure created by authors from Opinion Procedure Releases, U.S. DEP'T OF JUSTICE, http://www.justice.gov/criminal/fraud/fcpa/opinion (1993-2001) (last visited Feb. 15, 2013) and Review Procedure Releases, U.S. DEP'T OF JUSTICE, http://www.justice.gov/criminal/ fraud/fcpa/review (1980-1992) (last visited Feb. 15, 2013).

92. Table created by authors from Opinion Procedure Releases, U.S. DEP'T OF JUSTICE, http://www.justice.gov/criminal/fraud/fcpa/opinion (1993-2001) (last visited Feb. 15, 2013) and Review Procedure Releases, U.S. DEP'T OF JUSTICE, http://www.justice.gov/criminal/ fraud/fcpa/review (1980-1992) (last visited Feb. 15, 2013). 
consulting assistance @ $\$ 20,000$ for year)

93-01 (director's fee to FO)

88-01 (company constructing facility in Mexico must pay government and agent $\$ 362,000$ for debt/equity swap)

87-01 (fee to international marketing organization (10\%) to British co. that will then sell to Nigerian government)

86-01 (three companies pay three members of parliament in Great Britain and Malaysia between $\$ 36,000$ and $\$ 60,000$ each per year to represent their businesses)

85-03 (pay former government official)

85-02 (pay former government official)

84-01 (hire relative of FO)

82-04 (hire relative of FO)

82-03 (pay government agency)

82-02 (fee to temporary government official)

80-02 (employee running for office, could become FO)

Travel and Promotional Expenses (13)

11-01 (two days)

08-03 (an organization pays lodging and travel expenses for twenty journalists of Chinese SOE to attend press conference about NGO)

07-02 (six-day trip for six officials before six-week internship starts for foreign insurance regulators)

07-01 (four-day trip for six officials on "educational and promotional" tour of U.S. site)

04-04 (five foreign officials' "study tour" for drafters of new legislation on mutual insurance, $\$ 16,875$ )

04-03 (law firm to sponsor ten-day trip for twelve officials from China to educate them about labor and employment laws)

04-01 (law firm sponsors 1.5-day law seminar in China)

96-01 (non-profit to sponsor ten people for environmental training in the United States at $\$ 10,000$ to $\$ 15,000$ a year)

92-01 (company to provide training on petroleum industry to Pakistani officials, $\$ 200,000$ annually; Pakistan laws require this)

85-01 (ARCO, constructing a chemical plant in France, invites French officials to the United States to inspect a facility (unusual because company is named))

83-03 (Dept. Agriculture of Missouri and company pay Singapore official for 10 day visit to Missouri for inspections)

83-02 (pay for FO and wife to extend vacation and visit U.S. facilities; $\$ 5,000$ )

82-01 (Missouri Dept. of Agriculture to host ten Mexican FO to show products for sale) 
Due Diligence (5)

08-02 (Halliburton to acquire U.K. company but does not have time to do due diligence beforehand)

08-01 (Fortune 500 company to buy foreign company, of which majority owner is foreign government)

04-02 (JP Morgan Partners and others to purchase ABB Ltd., a company in the oil and gas business involving Nigeria, Angola and Kazakhstan, with 115 lawyers and 44,700 man hours)

03-01 (U.S. company. to purchase another U.S. company with operations overseas and found payments to $\mathrm{FO}$ )

01-03 (U.S. company bid to foreign government for equipment with help of dealer, may have made payment)

\section{$\underline{\operatorname{Other}(6)}$}

98-02 (payment to an individual as International Consultant to help with sale of military training programs; recipient is private $\mathrm{NGO}$ )

98-01 (pay $\$ 30,000$ to Nigerian Ports Authority for "community compensation")

97-01 (hiring representative with shady past)

84-02 (small payment to low level government employee to facilitate transfer of branch to a foreign company)

83-01 (California company to use Sudan company as agent but head of Sudan company appointed by President of Sudan)

80-03 (company hiring a West African attorney)

Joint Venture (4)

01-01 (U.S. and French company)

95-02 (2 companies to enter into joint venture with foreign government)

81-01 (Bechtel to do business with SGV, a Philippine company)

80-04 (Lockheed Martin and a Saudi company will do business with an airline company owned by the Saudi government)

\section{Gifts (4)}

09-01 (sample units to hospital, $\$ 1.9$ million)

06-01 (U.S. company in Switzerland to pay government in African country $\$ 25,000$ to help enforce anti-counterfeit laws)

80-01 (pay for children's tuition of honorary official)

81-02 (samples to FO) 


\section{Charity /donations (3)}

10-02 (\$1.42 million to microfinance entity of government)

97-02 (build elementary school)

95-01 (\$10 million to build medical facility)

Interestingly, "facilitation payments" were not specifically inquired about in the Opinion Releases. However, Opinion Release 84-02 (listed under "Other" in Table 1), which queried about a small payment to a lowlevel foreign official to transfer a branch to a foreign company, could be construed as a "facilitation payment." (also listed under "Other") involved $\$ 30,000$ in "community compensation" for the Nigerian Ports Authority, which could also be considered a facilitation payment. ${ }^{94}$ While there were inquiries about large gifts and charity donations, these are not the kind of "facilitation payments" envisioned by the 1988 amendments. One wonders why more questions regarding facilitation payments are not submitted to the DOJ. Conjecture suggests that "facilitation payments" are made on the spur of the moment, i.e. to move goods off the dock, and companies do not perceive they have the luxury of time to submit a query. If paid, facilitation payments should be recorded as such. Companies may have much stricter requirements, including advance permission and limits on payments, if they allow such payments at all. ${ }^{95}$

What does to "obtain or retain business" mean? While this seems clear, it is not. In an early US case, a small business owner pled guilty to a violation of the FCPA because he offered money to an agent who allegedly gave money to a foreign official so the seller would be paid for the milk powder he had already delivered overseas. ${ }^{96}$ Although Mr. Herzberg, the seller, believed that he had not violated the law, it was cost effective and provided certainty of punishment and costs to enter a plea agreement rather than the expensive and unpredictable route of testing the government's theory. A $\$ 20,000$ fine and probation was the cheaper exit. ${ }^{97}$ This section continues to have a broad reading both by the DOJ's interpretation and court cases. ${ }^{98}$ Philip Urofsky, a former DOJ official and now an attorney with Shearman and Sterling, LLP, has noted that payments to "custom or

93. See supra note 93.

94. Id.

95. See generally Cloudy with a Chance of Prosecution?, supra note 69 , at 567.

96. Exhibit B: Stipulated Facts and Application of the United States Sentencing Guidelines, U.S. DEP'T of JUSTICE, May 23, 1994, http://www.justice.gov/criminal/fraud/ $\mathrm{fcpa} /$ cases/vitusa/1994-05-23-vitusa-stipulated-facts.pdf.

97. Id. at 2 .

98. Id. 
tax officials to reduce duties and taxes, to expedite customs clearances or to evade import regulations" have all been interpreted to violate this section. ${ }^{99}$ In United States v. Kay, American Rice executives authorized payment to Haitian officials to reduce taxes on imports. The company self-reported, but the individuals nevertheless were tried, convicted, fined and sentenced to thirty-seven months and sixty-three months in prison, respectively. ${ }^{100}$ There does not appear to be a backpedaling on this broad interpretation by either the courts or the DOJ. The most recent wins by defense counsel in several cases have been mentioned in Part 1 .

While defining a foreign official may seem simple, it is actually more complex than first appearance would suggest. There is no question that a Minister of Defense of Country X, responsible for weapon procurement, is a foreign official under the FCPA. But what about a doctor in a community hospital run by the government in poor country Y? Does it depend on his position, or does the fact that he is a state employee amount to being considered a foreign official? Even if the doctor is deemed a foreign official, would it be considered a bribe if he or she accepted money from a pharmaceutical company to attend a conference about diabetes in the capitol which he or she otherwise would not be able to afford to attend? Is the pharmaceutical company risking prosecution by proceeding with this model of professional continuing education? Is this simply an academic problem and not a real life dilemma? The Opinion Procedures address this dilemma in part but do not definitely resolve the ambiguities; the Industry Codes discussed below reveal increasing concern, as well as ambivalence below the surface.

The situation described above is not an academic dilemma but rather a very real problem for many doctors working in South America, China and parts of Europe, as well as for companies that market to such professionals. While in the United States many doctors are not government employees, private hospitals are taking steps to limit drug companies' ability to sponsor lunches, dinners and other kinds of gifts that might possibly skew a doctor's interest in prescribing medications for other than the patient's best interests (e.g. kickbacks and other incentives), but this is based on a sense of ethics and not on the FCPA. Yet not all doctors work at Massachusetts General Hospital or the Cleveland Clinic. Many pharmaceutical companies and

99. Philip Urofsky, Recent Trends and Patterns in FCPA Enforcement, January 2012, 1949 PLI/CORP 167, 188 (2012) (mentioning the Panalpina cases).

100. Id. But cf. Editorial, Justice's Bribery Racket, WALL ST. J., Feb. 16, 2012, at A12 (describing the Justice Department as launching "creative prosecution," which because of some failures has given "a legal black eye [this phrase needs a grammatical object]," and commenting that "the Obama Administration's overzealous prosecution is leading to uncertainty and injustice" and that "Congress and the courts need to curtail this latest antibusiness crusade"); Mike Koehler, The Facade of FCPA Enforcement, 41 GEO. J. INT'L L. 907 (2010). 
associations have Guidelines about how to handle such promotions, sponsorships and the like, ${ }^{101}$ discussed in the following section.

\section{The Role of the Private Sector}

To reiterate, the conundrum highlighted here is very real and associated with potentially high economic and personal costs for making a decision deemed "wrong" by a court after the fact. The DOJ has explicitly acknowledged that "it is entirely possible, under certain circumstances and in certain countries, that nearly every aspect of the approval, manufacture, import, export, pricing, sale and marketing of a drug product in a foreign country will involve a "foreign official" within the meaning of the FCPA." ${ }^{102}$ In recent enforcement actions, the DOJ has focused on health care providers as "foreign officials" and has fiercely pursued global pharmaceutical companies, often highlighting travel and hospitality expenses deemed to be improper. ${ }^{103}$

Internationally, the director of the United Kingdom's SFO echoed these sentiments in remarks made in 2010 to the Association of the British Pharmaceutical Industry (hereinafter the "ABPI"), a group that sets self-

101. Gregory Husisian, The Foreign Corrupt Practices Act: Risk-Management and Compliance Strategies for Life Sciences and Pharmaceutical Companies, $1949 \mathrm{PLI} / \mathrm{CORP}$ 455,476 (2012).

102. See Breuer, supra note 59, at 1 :

I would like to share with you this morning one area of criminal enforcement that will be a focus for the Criminal Division in the months and years ahead and that's the application of the Foreign Corrupt Practices Act (or "FCPA") to the pharmaceutical industry. According to PhRMA's 2009 Membership survey, close to $\$ 100$ billion, or roughly one-third, of total sales for PhRMA members were generated outside of the United States, where health systems are regulated, operated and financed by government entities to a significantly greater degree than in the United States. As a result, a typical U.S. pharmaceutical company that sells its products overseas will likely interact with foreign government officials on a fairly frequent and consistent basis. In the course of those interactions, the industry must resist short-cuts. It must resist the temptation and the invitation to pay off foreign officials for the sake of profit. It must act, in a word, lawfully.

The exact same sentiment was reiterated by then Acting Attorney General Gary Grindler at the 2010 Compliance Congress. See Acting Deputy Attomey General Gary G. Grindler Speaks at the 2010 Compliance Week Conference, U.S. DEP'T OF JUSTICE (May 25, 2010), http://www.justice.gov/dag/speeches/2010/dag-speech-100525.html. See also Stay Tuned for More, FCPA PROFESSOR (May 2, 2011), http://www.fcpaprofessor.com/stay-tuned-for-more2; Gardiner Harris \& Natasha Singer, U.S. Inquiry of Drug Makers Is Widened, N.Y. TIMES, Aug. 14, 2010, at B1, available at http://www.nytimes.com/2010/08/14/health/policy/ 14drug.html?_r=4\&ref=todayspaper.

103. Breuer, supra note 59, at 2. See also Stay Tuned for More, FCPA ProfEssor, May 2, 2011, http://www.fcpaprofessor.com/stay-tuned-for-more-2; Harris \& Singer, supra note 103. 
regulating standards for the industry widely seen as best practices around the world. Suggesting that his office was working closely with the DOJ and the SEC by specifically sharing information on the pharmaceutical industry, ${ }^{104}$ he sounded a warning that was heard. Acting quickly, the ABPI revised its code regarding promotions and announced that, effective January 1, 2011, proper promotional aids would be limited to "medical and educational goods and services which enhance patient care, or benefit the NHS and maintain patient care." 105 Although appropriate promotions may have the name of the company providing them, they may not reference specific drugs and cannot be for personal benefit, even if minimal. Accordingly, coffee mugs and surgical gloves are examples of formerly ubiquitous promotions now improper under ABPI Guidelines. ${ }^{106}$

The ABPI also offers "[g]uidance on collaboration between healthcare professionals and the pharmaceutical industry"107 in which specific attention is paid to appropriate hospitality: it must be "secondary to the main purpose of any meeting ... and must never be excessive or out of proportion to the main purpose of the meeting." 108 Gifts, grants and donations to health professionals and related institutions are also addressed and explained in the Code of Practice and its Guidelines. The Prescription Medicine Code of Practice Authority (PMCPA) administers the ABPI Codes of Practice and investigates alleged abuses of its standards. ${ }^{109}$

Identical concerns are raised by another major industry group, the International Federation of Pharmaceutical Manufacturers and Associations (hereinafter the "IFPMA"), an international body whose code serves as a "floor" upon which national codes may build to address local concerns. It also serves as the self-regulatory organization in countries where more robust compliance efforts do not yet exist. ${ }^{110}$ The IFPMA updated and expanded its Code of Pharmaceutical Marketing Practices (hereinafter, the

104. Barry Vitou \& Richard Kovalevsky, SFO's Stark Warning to Pharmaceutical Companies: Act Now or Take Your Medicine, THEBRIBERYACT.COM, Nov. 6, 2010, $\mathrm{http} / /$ thebriberyact.com/2010/11/06/sfos-stark-warning-to-pharmaceutical-companies-actnow-or-take-your-lumps/.

105. Code of Practice for the Pharmaceutical Industry, PRESCRIPTION MEDICINE CODE OF PrACTICE AUTHORITY, 2012, at 26, http://pmcpa.org.uk/files/ABPI\%20Code\%202012.pdf. [hereinafter Code of Practice]

106. Id. at 27. See also Reputation, Ass'N OF THE BRITISH PHARM. INDUS., http://www.abpi.org.uk/our-work/reputation/Pages/default.aspx (last visited Feb. 15, 2013).

107. Guidance on Collaboration Between Healthcare Professionals and the Pharmaceutical Industry, Ass'N OF THE BRITISH PHARM. INDUs., http://www.abpi.org.uk/ourwork/library/guidelines/Documents/Guidance\%20on\%20collaboration.pdf (last visited Feb. 13, 2013).

108. Id. at 3.

109. Code of Practice, supra note 106.

110. IFPMA Code of Practice, INT'L FED'N OF PHARM. MFRS. \& Ass'NS, Mar. 5, 2012, http://www.policymed.com/2012/03/international-federation-of-pharmaceutical-manufactures-andassociations-ifpma-code-of-practice.html. 
"Code") in March 2012 to more effectively address pharmaceutical company interactions with medical schools and hospitals, patient organizations, and healthcare professionals, especially physicians. It, too, focuses on areas relevant to this discussion: clarifying proper payments to healthcare professionals for speaking, meetings, and other services; defining gifts and promotions as distinct from "items of medical utility" and requiring both to be modest in value; eliminating mention of cultural courtesy gifts; and requiring medical samples to be marked as such. ${ }^{111} \mathrm{~A}$ special note regarding "Guidance on Values" requires the IFPMA member associations to offer a "precise value" in local currency for promotional items of "nominal value" as well as for items of medical utility of "modest value." 112

The extent to which public sentiment has shifted regarding when is 'not a bribe' a bribe is thrown into stark relief when comparing the 2006 iteration of the IFPMA Code, which took the remarkable step at the time of prohibiting cash as gifts, to the detailed descriptions of permissible interactions now in place. Indeed, one analyst notes:

The revised IFPMA Code reflects the global industry trend to self-regulate pharmaceutical industry sales and marketing practices in the absence of clear regulatory guidance. The evolution of such Codes of Conduct also reflects recognition of an increasingly aggressive regulatory enforcement environment in which many in the industry are not certain of regulatory expectations or the limits of commercial speech. The revised IFPMA Code is also timely in view of the recent focus in the United States and elsewhere on practices relating to interactions with health care professionals, as evidenced by government investigations and actions under the Foreign Corrupt Practices Act (United States), the Bribery Act (United Kingdom) and other countries. ${ }^{113}$

111. Id. See also Overview of the Revised International Federation of Pharmaceutical Manufacturers \& Associations (IFPMA) Code of Practice, ARNOLD \& PORTER LLP, Mar. 2012, at 4-12, http://www.arnoldporter.com/resources/documents/Advisory\%20Overview Revised_International_Federation_Pharmaceutical_Manufacturers_\&_Associations_IFPMA _Code_Practice.pdf [hereinafter ONerview of the Revised IFPMA Code] (providing a chart comparing the 2006 IFPMA Code to the 2012 IFPMA Code).

112. IFPMA Code of Practice, INT'L FED'N OF PHARM. MFRS. \& Ass'NS, 2012, § 7.5.4, http://www.ifpma.org/fileadmin/content/Publication/IFPMA_Code_of_Practice_2012.pdf.

113. James S. Cohen et al., IFPMA Releases Revised Code for Interactions with Health Care Professionals and Other Stakeholders, Ass'N OF CORPORATE COUNSEL, Mar. 16, 2012, http://www.lexology.com/library/detail.aspx?g=f7894a7f-92fd-4967-9130-90d691054c87.

See also Samuel Rubenfeld, Pharma Code Revamp Follows US Industry, WaLL ST. J. 
Enforcement under the IFPMA Code is left to each member country to handle under its own codes, unless there is no national code or appropriate law in the country where the complaint originates. If the IFPMA Code is found to have been breached, IFPMA will publish the name of the offending company; where there is a complaint but no breach, a summary of the case is made available on its website. ${ }^{114}$ Of course, critics look more to the walk than to the talk: in the past five years only four enforcement actions have been taken by the IFPMA in the form of public disclosure of violation of the Code, although more cases have been handled by member organizations. ${ }^{11}$

Likewise, the European Federation of Pharmaceutical Industries and Associations (EFPIA) promulgated a Code on the Promotion of Prescription-Only Medicines to, and Interactions with, Healthcare Professionals with amendments effective January 1, 2012. ${ }^{116}$ Again, the focus of this code is to highlight the risk associated with promoting drugs in a manner that may be perceived as corrupt even if the transaction is relatively modest or even de minimis.

Similar to its international counterparts, the US industry group, PhRMA, issued its updated voluntary Code on Interactions with Healthcare Professionals effective January 2009. It specifically permits providing meals to physicians as part of informing them about medicines on the condition that the meals "(a) are modest as judged by local standards; (b) [not] part of an entertainment or recreational event; and (c) are provided in a manner conducive to informational communication." 17 Entertainment and recreational enticements such as tickets to sporting events, the theater, or to a vacation spot are prohibited, even if modest in value or secondary to an educational purpose. ${ }^{118}$ Specific attention is given to "continuing medical education grants," which must not be seen as "an inducement to prescribe or recommend a particular medicine or course of treatment." 119 Cash gifts may not be given directly to a healthcare professional for conference support, but may be offered to the conference sponsor on the

CORRUPTION CURRENTS BlOG, Mar. 1, 2012, http://blogs.wsj.com/corruption-currents/2012/ 03/01/pharma-code-revamp-follows-us-industry-sweep/.

114. Overview of the Revised IFPMA Code, supra note 111, at 3. .

115. Reuters, Global Drug Industry Tightens Anti-Corruption Code, LAHORE Times, Mar. 4, 2012, available at http://www.lhrtimes.com/2012/03/04/global-drug-industry-tightensanti-corruption-code/.

116. EFPIA Code on the Promotion of Prescription-Only Medicines to, and Interactions with, Healthcare Professionals, EUROPEAN FED'N OF PHARM. INDUS. \& Ass'Ns, June 14, 2011 (amended), available at http://www.efpia.eu/sites/www.efpia.eu/files/EFPIA \%20Code_ Promotion_HCP_-_11.06.14_FINAL_EDITING_07-08-11-mcp-20110630-002-EN-v1_1.pdf.

117. Code on Interactions with Healthcare Professionals, PHARM. RESEARCH \& MFRS. OF AM., 2008, at 4, available at http://www.phrma.org/sites/default/files/108/phrma_marketing_ code_2008.pdf.

118. Id. at 5 .

119. Id. at 6 . 
condition that the sponsor retains authority over content decisions.. ${ }^{120}$

Finally, Congress has taken a step toward clarifying the conversation about what is "value" in the pharmaceutical context. The Physician Payment Sunshine Act, proposed in 2009 by Senators Charles Grassley (RIowa) and Herb Kohl (D-Wisconsin) and embedded in the Patient Protection and Affordable Care Act, sets up a two-step process to create transparency regarding "payments and other transfers of value provided to physicians and teaching hospitals for a wide array of purposes-from consulting to food and travel." 21 The statute offers a list of payments to be reported, ranging from "gift, food, entertainment, travel or trip" to the more obvious "dividends, profit distribution, stock or stock option grant" if worth more than ten dollars. ${ }^{122}$ The data must be recorded effective January 1 , 2012, reported in March 2013, and posted on public and searchable databases starting September 2013 and every year thereafter. ${ }^{123}$ It appears that although the industry giants are already reporting transactions with healthcare entities, most are waiting for the implementing regulations to become effective. ${ }^{124}$

Very obviously, the private sector is confused by the state of the law both in the United States and abroad; predictably, it is reacting in a rather rational manner. The Deloitte Anticorruption Practices Survey $2011^{125}$ of 276 executives revealed that $47 \%$ of companies prohibited facilitating payments in all cases, $36 \%$ allowed them with preapproval and only $5 \%$ allowed them with no restrictions. ${ }^{126}$ Of the combined percentage of companies that permit some type of facilitating payment, $4 \%$ allowed between $\$ 250$ - $\$ 499 ; 7 \%$ allowed up to $\$ 500 ; 13 \%$ percent allowed $\$ 100$ -

120. Id. at 12 .

121. Physician Payments Sunshine Act of 2009, S. 301, 111th Cong. (2009) (later incorporated as $\S 6002$ of the Patient Protection and Affordable Care Act of 2010, Pub. L. No. 111-148, 124 Stat. 119 (2010)) [hereinafter Physician Payments Sunshine Act]. "On December 19, 2011, the Centers for Medicare \& Medicaid Services (CMS) published a proposed rule implementing the Physician Payments Sunshine Act ... . During the sixty-day comment period, CMS received over 300 comments from a wide range of stakeholders." Information on Implementation of the Physician Payments Sunshine Act, CMS BLOG (May 3, 2012), http://blog.cms.gov/2012/05/03/information-on-implementation-of-the-physician-paymentssunshine-act/.

122. Physician Payments Sunshine Act, supra note 121. See also Physician Payment Sunshine Provisions: Patient Protection Affordable Care Act Passed the House, Policy \& MEDICINE (Mar. 22, 2010), available at http://www.policymed.com/2010/03/physicianpayment-sunshine-provisions-patient-protection-affordable-care-act.html.

123. Arlene Weintraub, New Health Law Will Require Industry to Disclose Payments to Physicians, KAISER HEALTH NEws (Apr. 26, 2010), http://www.kaiserhealthnews.org/ Stories/2010/April/26/physician-payment-disclosures.aspx.

124. Id.

125. Cloudy with a Chance of Prosecution?, supra note 69, at 567.

126. Id. 
$\$ 249 ; 23 \%$ allowed under $\$ 100$; and $53 \%$ had no restrictions. ${ }^{127}$

Interestingly, Deloitte reported that "[r]elatively few executives were very confident in the effectiveness of their company's anticorruption program" 128 and noted that "many companies are now eliminating these payments" to be safe. ${ }^{129}$

In several areas, executives at larger companies were more likely to perceive greater risk. Given the widespread use of third parties to provide services, raw materials or manufactured goods, 63 percent of executives at larger companies believed the use of third parties posed a significant risk, compared to 33 percent of those at smaller companies. Similarly, 35 percent of executives from larger companies perceived significant risk from entertainment or business development expenses related to government business or to government relations while only 19 percent of those at smaller companies shared that concern. ${ }^{130}$

The smaller companies do not have the resources to mount serious compliance efforts and they do not necessarily even appreciate the risk they are facing. ${ }^{131}$ This study demonstrates the concerns executives have in trying to operate within this landscape and still comply with both domestic and foreign laws. ${ }^{132}$

Ernst \& Young also conducted a survey and reported " $15 \%$ of surveyed firms think cash payments to win business can be justified if they help companies survive an economic downturn compared with $9 \%$ last year. " $" 133$ Is that number a reflection of hard-nosed willingness to breach laws perceived to be unjust or at a minimum, unclear? Or, is it instead a

127. Id.

128. Id. at 568 .

129. Id. at 567 .

130. Id. at 569 .

131. See Beverley Earle, Because It's the Bottom Line: The Need for Corporate Compliance Programs for Small-and Medium-Size Businesses, 25 Bus. ForUM: J. SCH. Bus. \& ECON. 3, 3-6 (2000) (discussing how the Organizational Sentencing Guidelines in 1991 ensnared many small businesses).

132. Id.

133. You Get Who You Pay For: The Economic Case for Bribery, ECONOMIST, June 2, 2012, available at http://www.economist.com/node/21556255/print (discussing an Ernst \& Young global fraud survey noting that $39 \%$ of businesses believe that corruption is "common" where they operate; citing research that shows the efficacy of bribing and the return on investment for some firms but also noting that "[a]nother paper, by Jonathan Karpoff of the University of Washington, Scott Lee of Texas A\&M University and Gerald Martin of American University, found that American firms facing bribery-enforcement action lose $9 \%$ of their market value, mostly because they have other problems with misrepresentation and fraud."). 
reflection of progress in reducing the willingness to make such payments from earlier and presumably higher levels? The efforts of the pharmaceutical industry to keep abreast of and even ahead of the legal curve point to the latter, in our opinion. Nonetheless, international sentiment seems to be moving in the direction of more regulation of even the smallest of payments that might be perceived to be facilitating business.

\section{E. The International Direction on the Issue of Facilitation Payments}

A survey conducted of thirty-nine signatory countries of the OECD Convention found that eleven of the thirty-nine had adopted the facilitation exception including Australia, Austria, Canada, Greece, South Korea, New Zealand, Slovak Republic, South Africa, Spain, Switzerland, and the United States. ${ }^{134}$ Countries that in theory do not allow such payments include Argentina, Belgium, Brazil, Bulgaria, Chile, Czech Republic, Denmark, Estonia, Finland, France, Germany, Hungary, Iceland, Ireland, Israel, Italy, Japan, Luxembourg, Mexico, Netherlands, Norway, Poland, Portugal, Russia, Slovenia, Sweden, Turkey and the United Kingdom. ${ }^{135}$ Yet, we know from the detailed discussion of the U.K. law that although theoretically not allowed, these instances will not be prosecuted they are not given for a corrupt purpose and are essentially a "grease payment." "136

Similar to the US Physician Sunshine Act, France proposed a law that requires more disclosure of industry interactions with health care professionals and hospitals. In what has been called a "draconian" law, ${ }^{137}$ the so-called French Sunshine Act mandates disclosure of anything of value starting in August 2012. The nature of "value" has not yet been defined, but an amount of approximately 150 Euros has been discussed. ${ }^{138}$ Other European countries are considering enacting specific pharmaceutical industry disclosure mandates, while others still treat the issue as arising under their anti-bribery framework. ${ }^{139}$

134. Andy Spaulding, Facilitating Payments (De)mystified (Part II), FCPA BLoG (June 13, 2012), http:/www.fcpablog.com/blog/2012/6/13/facilitating-payments-demystified-part-ii.html.

135. Id.

136. See OECD Anti-Bribery Convention, supra note 29, at Commentary Art.1, ๆ 9.

137. Declan Butler, France Toughens Conflict Rules, NATURE (Oct. 11, 2011), available at http://www.nature.com/news/2011/111011/full/478169a.html.

138. France: A "Sunshine Act" for the Healthcare Industry, Covington \& BURLING LLP (Jan. 20, 2012), http://www.cov.com/files/Publication/a9966e5e-0fa3-467a-b78c-428aaa262fd3/ Presentation/PublicationAttachment/79d4ac88-ac3f-4841-a2c1-4a5f917b6ecf/France\%20$\% 20 \mathrm{~A} \% 20$ Sunshine $\% 20 \mathrm{Act} \% 20$ for $\% 20$ the $\% 20$ Healthcare $\% 20$ Industry.pdf.

139. Interactions Between Life Sciences Companies and Health Care Professionals: Can the French Sunshine Act Push Transparency So Far?, BAKER \& MCKENZIE LEGAL ALERT(Apr. 13, 2012), http://www.bakermckenzie.com/files/Publication/976c4652-1c6d-4fa6-adb8-f85705a23f05/ Presentation/PublicationAttachment/d4893957-c26b-403c-97b5-0a6f93019cc9/al_paris_ frenchsunshineact_apr12.pdf. 


\section{F. The Possibility of Change}

The evolution of law and public opinion about bribery is an interesting one. When the FCPA was enacted in 1978, many thought it was laughable and would never be taken seriously. There was insignificant progress for twenty years, and then the OECD embraced the principles of the FCPA in the OECD Convention. This signaled a sea change in thought leaders' opinions about the evils of bribery and the possibility of eradicating it. ${ }^{140}$ Yet just as drunk driving has evolved from inevitable fact of life to being a crime, world opinion has shifted toward eradicating bribery. ${ }^{141}$ It will increase the pressure on the activity and eventually push for a more rare violation of law in foreign countries. The following graphic illustrates the model of change.

140. For a review of the literature see generally Beverley Earle \& Anita Cava, Are AntiCorruption Efforts Paying Off? International and National Measures in the Asia-Pacific Region and Their Impact on India and Multinational Corporations, 31 U. HAW. L. REV. 59, 66-70 \& nn. 38-47 (2008) (discussing and citing, inter alia, KIMBERLY ANN ELLIOT, CORRUPTION AND THE GLOBAL ECONOMY (Kimberly Ann Elliot ed., 1997; INTERNATIONAL HANDBOOK ON THE ECONOMICS OF CORRUPTION (Susan Rose-Ackerman, ed., 2006); JOHN T. NOONAN, BRIBES (1984); SUSAN ROSE-ACKERMAN, CORRUPTION AND GOVERNMENT: CAUSES, CoNSEQuENCES, AND REForm (1999); SUSAN Rose-ACKerman, CORRUPTION: A STUdy IN Political ECONOMY (1978); Beverley Earle, The United States' Foreign Corrupt Practices Act and the OECD Anti-Bribery Recommendation: When Moral Suasion Won't Work, Try the Money Argument, 14 Dick. J. INT'L L. 207 (1996); Beverley H. Earle, Foreign Corrupt Practices Act Amendments: The Omnibus Trade and Competitiveness Act's Focus on Improving Investment Opportunities, 37 CLEV. ST. L. REV. 549 (1989); Paolo Mauro, Corruption and Growth, 110 Q. J. ECON. 681 (1995); Susan Rose-Ackerman, Political Economy of Corruption, in CORRUPTION AND THE GLOBAL ECONOMY 31-60 (Kimberly Ann Elliot ed., 1996; Andrei Schleifer \& Robert Vishny, Corruption, 108 Q. J. ECON. 599 (1993); Claire Taylor, Bribery in Athenian Politics Part II: Ancient Reaction and Perceptions, 48 GREeCE \& Rome 154 (2001); Bribonomics: Does Corruption Hinder Economic Growth?, ECONOMIST, Mar. 19, 1994).

141. Beverley Earle \& Anita Cava, Are Anti-Corruption Efforts Paying Off? International and National Measures in the Asia-Pacific Region and Their Impact on India and Multinational Corporations, 31 U. HAW. L. REV. 59, 85 (2008) (making the analogy to drunk driving). 


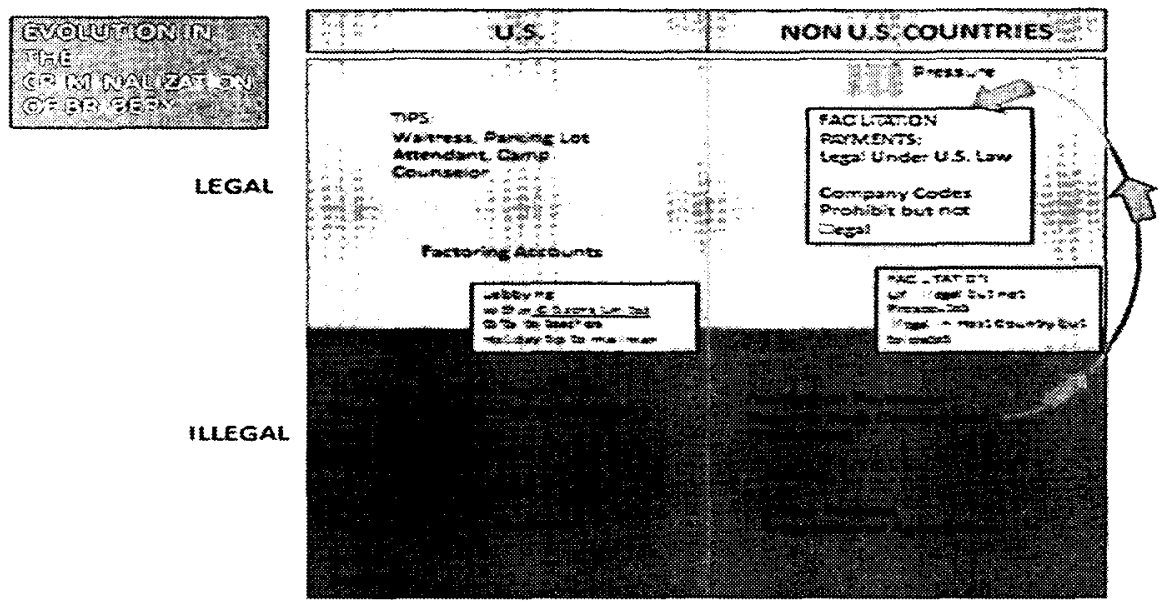

\section{Figure 2 - Evolution in the Criminalization of Bribery}

Alan Dershowitz, the Felix Frankfurter Professor of Law at Harvard Law School, has cautioned that:

[t]he criminal law should be limited to... 'Hamlet decisions.' Before a person is charged with serious crime, the government should have to prove beyond a reasonable doubt that the defendant actually engaged in a 'to be or not to be' decision - to be a felon or not to be a felon, to step over a clear line that separates criminality from $\sin ^{142}$

He further reminds us that criminalizing conduct that is vague and not well understood serves to undermine the basis of our republic. Yet as the court in United States v. Kay ${ }^{143}$ stated, persons prosecuted for violation of the FCPA only needed to know "generally that their actions were

142. Alan Dershowitz, Edwards Jury Got It Exactly Right, CNN OPINION (May 31, 2012), http://articles.cnn.com/2012-05-31/opinion/opinion_dershowitz-edwards-verdict_1_reasonabledoubt-criminal-case-criminal-justice-system?_s=PM:OPINION.

There is no reason to believe that John Edwards ever made that decision because the law governing his conduct is vague, subjective and unclear in the extreme. At the time of the founding of our Republic there was a common expression that said that a criminal law must be so clear that a potential defendant 'can read it while running and still understand it.' The law under which Edwards was tried was so unclear that a bevy of lawyers could not understand it while sitting and studying it for hours .... If Congress wants to criminalize what Edwards was accused of doing, let it enact a clear law that gives fair warning to all politicians that they may not accept any gifts regardless of intent. I doubt Congress will pass such a law.

143. United States v. Kay, 200 F. Supp. 2d 681 (S.D. Tex. 2001), aff d following remand, 513 F.3d 432 (5th Cir. 2007). 
illegal." $" 144$ They did not have to possess specific knowledge about the statute. Given that the FCPA has been in place for thirty-four years, it is fair to say that people understand that bribery is unlawful. Yet, even some people can be mistaken about what constitutes a permissible facilitation payment and whether their decisions qualify for "allowed" promotional expenses. Thus, a number of proposals to correct perceived errors of the legislation have been proffered.

\section{EXAMINING CURRENT PROPOSALS FOR FCPA REFORM}

Michael B. Mukasey, a partner at Debevoise \& Plimpton, LLP and a former federal judge and United States Attorney General, speaks for a group of business people who have raised concerns about the current FCPA enforcement environment ${ }^{145}$ and makes the following argument:

In our view, these expansive interpretations and aggressive FCPA enforcement actions stray far from the FCPA's basic purpose: preventing corruption and bribery. It is largely pointless to punish corporations whose executives, for example, had no knowledge of misconduct occurring at a subsidiary, perhaps prior to its acquisition, or that had programs and policies designed to prevent the very conduct that took place. Such enforcement actions do not deter because a corporation cannot be deterred from doing something it did not set out to do in the first place. Instead, such enforcement punishes companies' management for not correctly anticipating the prosecutor's latest theory about the reach of the FCPA. This places U.S. corporations at unease by subjecting them to the possibility of large, unforeseen civil and criminal penalties for conduct they are often powerless to define and therefore powerless to prevent. ${ }^{146}$

We believe, however, that these problems could be mitigated, and the FCPA strengthened, by few relatively simple fixes. Because the FCPA will never be heavily litigated-thus depriving the courts of the opportunity to clarify its murky text-Congress must speak clearly about

144. Kay, 513 F.3d at 446-51. See also Client Alert: United States Supreme Court Denies Certiorari in Controversial Foreign Corrupt Practices Act Case: Expansive Enforcement of the FCPA Likely to Continue, ChADBOURNe \& PARKE LLP, Oct. 13, 2008, http://www.chadbourne.com/clientalerts/2008/fcpa/.

145. Mukasey \& Dunlop, supra note 68 , at 31 .

146. Id. 
what conduct does and does not violate the FCPA. ${ }^{147}$

He proposes six changes to the statute, including adding a "compliance defense," "[c]larify[ing] the meaning of "foreign official,", "[i]mprov[ing] the procedures for guidance and advisory opinions from [the] DOJ," "[l]imit[ing] criminal successor liability for acquiring companies," "[a]dd[ing] a 'willfulness' requirement for corporate criminal liability," and "limit[ing] a company's liability for acts of a subsidiary not known to the parent."

Representative James F. Sensenbrenner of Wisconsin, the chair of the Subcommittee on Crime Terrorism and Homeland Security, opened hearings on the FCPA on June 14, 2011 by stating:

America is suffering through a severe and prolonged economic downturn. Businesses that are trying to comply with the FCPA assert that the law is being enforced in a vague and impenetrable manner. Because the risks of prosecution are so great, with million-dollar fines and possible prison sentences, companies would rather settle with the Justice Department than go to court. ${ }^{149}$

Both sides of the debate voiced strong opinions at the hearing. Not surprisingly, Greg Andres, Deputy Assistant Attorney General of the DOJ's Criminal Division, defended the existing statute and prosecutions for violations of its prohibitions. He argued that the department provided sufficient guidance via the Opinion Procedures and touted that process as "unique in U.S. criminal law." 150 His written statement offered a detailed listing of recent enforcement actions and he specifically pointed out that, contrary to the claim that the term "foreign official" is not clear, there are five advisory opinions addressing the definition of that term. ${ }^{15}$

Furthermore, Judge Mukasey raised the business argument in support of in comments supporting his six proposed amendments to the FCPA:

The system now in place has conflicting incentives. On the one hand, an effective compliance program can hold out a

147. Id.

148. Id.

149. Foreign Corrupt Practices Act: Hearing Before the Subcommittee on Crime, Terrorism, and Homeland Security of the Committee on the Judiciary of the House of Representatives, 112 Cong. 2 (2011) (statement of Rep. and Chairman Sensenbrenner Jr.).

150. Id. at 7 (testimony of Greg Andres, Deputy Assistant Attorney General, Criminal Division, U.S. Dep't of Justice).

151. Id. at 17 (written statement of Greg Andres, Acting Deputy Assistant Attorney General, Criminal Division, U.S. Dep't of Justice). 
qualified promise of indeterminate benefit should a violation occur and be disclosed. On the other hand, if all that can be achieved is a qualified and indeterminate benefit, there is a perverse incentive not to be too aggressive lest wrongdoing be discovered, and there is a resulting tendency of standards to sink to the level of the lowest common denominator, or at best something that is only a slight improvement over it. This Catch-22 policy doesn't really serve anyone's interest. ${ }^{152}$

He made reference to Title VII of the Civil Rights Act of 1964, which allows a compliance defense, underlining its importance as an incentive for companies to work to prevent this problem. ${ }^{153}$ stating:

George Terwilliger, a partner at White \& Case, LLP also testified,

At the outset, I would like to put my further remarks in this context. I favor the fair enforcement of sensible anticorruption statutes because corrupt markets cannot be free markets. In international commerce specifically, a level playing field is essential to free-market competition, and I believe American businesses are well positioned to succeed in free and fair competition....

But there is another less desirable effect that results from the combination of greatly stepped up enforcement combined with the uncertainty of the precise legal parameters of conduct subject to the requirements and proscriptions of this statute. That hidden effect is the cost imposed on our economic growth when companies forgo business opportunity out of concern for FCPA compliance risk. This hurts the creation of jobs and the ability of U.S. companies to compete with companies elsewhere that do not have to concern themselves with uncertainties of the terms of requirements of the FCPA. ${ }^{154}$

Adding to the chorus of concern, Shana-Tara Regon, Director of White Collar Crime Policy, National Association of Criminal Defense Lawyers, also addressed the committee, stating:

152. Id. at 19 (testimony of the Honorable Michael Mukasey, former Attorney General, Partner, Debevoise \& Plimpton LLP).

153. Id. at 19.

154. Id. at 37 (testimony of George J. Terwilliger, III, Partner, White \& Case). 
Because there has been so little judicial scrutiny of FCPA enforcement theories, right now the FCPA essentially means whatever the DOJ and SEC says it means.

Significantly, DOJ has been allowed to use the law as if it were virtually a strict liability statute, meaning that actual knowledge of wrongdoing does not need to be proved. Such an application is inconsistent with notions of fundamental fairness. In addition, because the reach of the FCPA is so vast and its provisions so amorphous, DOJ now oversees and regulates virtually all American companies and individuals seeking to do business abroad in ways that those who created the FCPA never could have envisioned. $^{155}$

She noted that although Deputy Assistant Attorney General Andres said that they would not go after "de minimus activity," "[w]e need more clarity in the law." $" 156$ In her written comments, Director Regon further stated:

Defining broad categories of conduct as criminal will not eliminate all wrongdoing and criminalizing vast swaths of activity will not make America a better place. Indeed, for the first 100 years of our history, we had no federal prisons (except to house soldiers) and we started off with only three federal crimes - treason, piracy and counterfeiting. Now we have over 4,450 federal criminal laws on the books plus so many additional criminal provisions hidden in the federal regulatory scheme that no one has yet been able to count them. The average American is likely unaware of most of the criminal laws that could subject him or her to prosecution by the government. Many federal criminal statutes are duplicative of state criminal laws, and many more are duplicative of each other. Further, these federal laws are sometimes written broadly, with vague terms, and supported by questionable constitutional authority.

The FCPA is emblematic of the serious problem of overcriminalization. While the FCPA properly seeks to prevent and redress serious misconduct, its language and

155. Id. at 46 (testimony of Shana-Tara Regon, Director, White Collar Crime Policy, National Association of Criminal Defense Lawyers).

156. Id. at 47. 
application have led to unintended consequences .... [W]e join many other organizations, on both the left and the right in the call for some much-needed commonsense reform in this area, particularly reforms that will strengthen the mens rea requirements of the statute and bring clarity, uniformity and fairness to its enforcement. ${ }^{157}$

Deputy Assistant Attorney General Andres asserted, "the Department of Justice has never prosecuted somebody for giving a cup coffee to a foreign official, a martini, two martinis, a lunch, a taxi ride, or anything like that. And it is not clear that those acts in and of themselves would evidence an intent to bribe somebody." "158 When asked then if he would object to excluding coverage over de minimis payment, Deputy Assistant Attorney General Andres replied: "I would, for a few reasons. One small de minimis payment paid over time on multiple occasions can amount to a more significant bribe if, in fact, there is an intent to bribe. I think the relevant consideration is not the amount of the bribe but rather the intent ...."159

However, Deputy Assistant Attorney General Andres' dismissal of this problem for companies was undercut by Judge Mukasey, who stated:

The taxi ride example is for real. It occurred at a company in which somebody worked overtime, was given a taxi because the trains had stopped running, and then some nervous counsel found out about it, reported it to the Justice Department and was told that it probably wasn't a violation but to go back and investigate the entire circumstances of the relationship with that company and come up with a result of that investigation to determine that no illegal payments had been made. A couple of hundred thousand dollars later it was determined that, in fact, there had been no violation. ${ }^{160}$

This underscores many businesses' viewpoint of the cost of this broad

157. Id. at $47 \& 53$ (written testimony of Shana-Tara Regon, Director, White Collar Crime Policy, National Association of Criminal Defense Lawyers) (citations omitted); $c f$. Harvey A. Silverglate, Three Felonies a Day: How the Feds Target the InNocent (2009) (discussing the problem of over-criminalization).

158. Foreign Corrupt Practices Act: Hearing Before the Subcommittee on Crime, Terrorism, and Homeland Security of the Committee on the Judiciary of the House of Representatives, 112 Cong. 56 (2011) (testimony of Greg Andres, Deputy Assistant Attorney General, Criminal Division, U.S. Dep't of Justice, in response to a question by Rep. Robert Bobby Scott of Virginia).

159. Id.

160. Id. at 56-57 (testimony of the Hon. Michael Mukasey, former Attorney General, Partner, Debevoise \& Plimpton LLP). 
legislation on the bottom line.

Representative Conyers illustrated the opposite viewpoint in the hearing. He rebutted that there is over-criminalization by the DOJ or a problem with vagueness. He disputed that there had been a lot of cases, noting that there have been only 140 cases in ten years. ${ }^{161}$

Deputy Assistant Attorney General Andres confirmed that there were guiding sources already available for companies. ${ }^{162}$ Although seemingly contradicting Representative Conyers, Deputy Assistant Attorney General Andres suggested that there are more prosecutions now because: (1) email has made the world smaller and information moves more quickly; and 2) because Sarbanes-Oxley requires CEOs to verify financial statements and in so doing, these CEOs recognized their problems with bribery which resulted in self-reporting and consequently more enforcement. ${ }^{163}$ Deputy Assistant Attorney General Andres stated:

Just so I am clear, with respect to whether or not we can, there are within the statute exceptions for reasonable and bona fide promotional expenses. There are also other exceptions that cover legitimate business expenses. So if a cup of coffee is given to a foreign official without an intent to bribe that individual, we would not be able to bring that case because there is not the requisite intent to bribe. ${ }^{164}$

However, the problem with this analysis is, how does a corporation have an intent to bribe? ${ }^{165}$

A number of parties also submitted statements to the hearing committee but did not testify. Global Witness, a non-governmental organization, reiterated the need to curb bribery by stating, "In short, for the U.S. to roll back any of its ground-breaking anti-bribery law at this critical juncture when the rest of the world is finally starting to match its standard, would be an abdication of its leadership role on this important issue.,"166

Karen Lissakers, Director of Revenue Watch Institute, concurred that the Chamber of Commerce has picked an odd time "to assault" the

161. Id. at 60 (testimony of the Hon. John Conyers, Jr., a Representative in Congress from the State of Michigan and Ranking Member, Committee on the Judiciary).

162. Id. at 62 (testimony of Greg Andres, Deputy Assistant Attorney General, Criminal Division, U.S. Dep't of Justice).

163. Id. at 63.

164. Id. at 64 .

165. Cf. id. at 64 (testimony of Mr. Terwilliger, Partner, White \& Case LLP)

("The problem with a willfulness requirement for corporations is just what General Mukasey mentioned. Corporations can't think; only individuals can think. And therefore any ascribing of an intent to a corporation is really artificial because the corporation itself is artificial.").

166. Id. at 80 (written testimony of Global Witness). 
FCPA. ${ }^{167}$ She continued: "Congress should reject any effort to weaken the US anti-bribery statute and instead continue to advance policies that promote honest business and transparent and accountable governance around the world." 168

CREW, Citizens for Responsibility and Ethics in Washington, D.C., argued that Congress should "protect and maintain the Foreign Corrupt Practices Act," and that a "materiality requirement ignores the reality of how bribery works." ${ }^{169}$ They continued:

Congress understood when enacting the FCPA that corruption often takes the form of small "gifts" or payments made repeatedly over time. A stream of benefits is often part of a larger scheme. Moreover, a review of enforcement action shows small gifts made over time have never been the primary basis for FCPA actions, which instead focus on larger payments. ${ }^{170}$

The Open Society Foundation agreed: The "U.S. should focus on encouraging worldwide enforcement, not crippling a statute that has been the model for international anti-bribery legislation." 171 In 2011, the Foundation also issued a paper written by Professors David Kennedy of Harvard University and Dan Danielsen of Northeastern University School of Law titled, "Busting Bribery: Sustaining the Global Momentum of the FCPA" that responded to the proposals of amendments to the FCPA included in the document issued in October 2010 by the U.S. Chamber of Commerce Institute for Legal Reform, entitled "Restoring Balance." 172

[T] he Chamber proposes to change the Act in ways that would substantially undermine the possibility for successful enforcement of America's anti-bribery commitments. The Chamber's proposed amendments would also set back decades of progress in the global struggle against

167. Id. at 81 (written testimony of Karin Lissakers, Director, Revenue Watch Institute).

168. Id. at 83 .

169. Id. at 86 (written testimony of Citizens for Responsibility and Ethics in Washington).

170. Id.

171. Id. at 87 (written testimony of The Open Society Foundation).

172. David Kennedy \& Dan Danielson, Busting Bribery: Sustaining the Global Momentum of the Foreign Corrupt Practices Act, OPEN SOCIETY FoundaTIONS, Sept. 2011, http://www. opensocietyfoundations.org/sites/default/files/Busting\%2520Bribery201 iSeptember.pdf [hereinafter Busting Bribery] (responding to Restoring the Balance: Proposed Amendments to the Foreign Corrupt Practices Act, U.S. ChAMBER INSTITUTE FOR LEGAL REFORM, Oct. 2011, $\mathrm{http}: / / \mathrm{www}$.instituteforlegalreform.com/sites/default/files/restoringbalance_fcpa.pdf). 
corruption ... ${ }^{173}$

In addition, the Chamber's proposals would needlessly hamstring what has been a judicious and increasingly effective use of prosecutorial discretion to encourage compliance and isolate the most egregious violations. ${ }^{174}$

They dispute that prosecutorial overreach is a problem and they dismiss it as being speculative.

This is not the moment for the United States to abandon its decades-long leadership in the struggle to bend the culture of global business away from scourge of corruption. Widespread corruption abroad imposes enormous costs on American business, damages the global business environment and undermines the integrity and effectiveness of governments. A culture of corruption raises the costs of penetrating foreign markets and undermines predictability and business confidence. It imposes particular hardships on small and medium sized American enterprises seeking to participate in the global economy. Fighting these obstacles to American business has required a long-term commitment by the U.S. government and by American companies to change the climate for global commercial activity and the culture of business-government relations in countries across the world. ${ }^{175}$

Professors Kennedy and Danielson conclude:

As the global campaign turns toward strengthened enforcement and the administrative routinization of anticorruption commitments, it will be particularly important for American authorities, led by the DOJ and the SEC, to retain the traditional flexibility, their commitment to a level playing field, and their emphasis on private sector compliance and monitoring as the most effective tools in the battle against corruption. The Chamber's misleading rhetoric notwithstanding, the global trends are all good, the

173. Busting Bribery, supra note 173 , at 5 .

174. Id. at 6 .

175. Id. at 8 . 
FCPA is working and new legislation is not necessary. ${ }^{176}$

The dichotomy between the two sides is clear.

Subsequent to this hearing, the DOJ promised to issue clarifying guidelines in 2012. ${ }^{177}$ To date, however, none have been issued.

The Chamber of Commerce and thirty-three other groups, including the American Institute of Certified Public Accountants, wrote a letter in February of 2012, suggesting items the DOJ might incorporate into any guidelines: $^{178}$

[W]e believe that modest legislative revisions and clarifications of the FCPA remain the best option for providing the certainty needed by the regulated community. Nevertheless, the formal guidance that we understand you will provide in 2012 should carry sufficient precedential weight to be reliable and meaningful for businesses seeking to comply with the FCPA. ${ }^{179}$

The letter focused on several items including:

1. The Definition of "Foreign Official" and "Instrumentality", "180: Noting that these terms have been defined "broadly" but not in a "uniform" way, and citing the benchmark Lindsey Manufacturing case, the letter points out:

Courts have treated the issue as multi-faceted and highly fact specific, holding recently that Congress did not intend either to include or to exclude all state-owned enterprises from the ambit of the FCPA, and that whether a state-owned enterprise qualifies as an "instrumentality" is a question of fact for the jury to decide based upon a variety of factors, including the level of investment in the entity by a foreign state, the foreign state's

176. Id. at 52 .

177. Lanny Breuer, Assistant Attorney General Lanny A. Breuer Speaks at the 26th National Conference on the Foreign Corrupt Practices Act, U.S. DEP'T OF JUSTICE, Nov. 8 , 2011, http://www.justice.gov/criminal/pr/speeches/2011/crm-speech-111108.html.

178. Letter to the Honorable Lanny A. Breuer (Assistant Att'y Gen., Criminal Division, Dep't of Justice) \& Robert Khuzami (Director of Enforcement, U.S. Securities \& Exchange Comm'n) from the U.S. Chamber of Commerce et al., Feb. 21, 2012, http://www.instituteforlegalreform.com/sites/default/files/FCPA\%20Guidance\%20Letter-221-12_4_.pdf [hereinafter Letter to the Honorable Lanny A. Breuer].

179. Id. at 10.

180. Id. at 2 . 
characterization of the entity and its employees, the purpose of the entity's activities, the entity's obligations and privileges under the foreign state's law, the circumstances surrounding the entity's creation and the foreign state's extent of ownership of the entity. ${ }^{181}$

Consideration of Compliance Programs in Enforcement Decisions: Although the DOJ's Principles of Federal Prosecution of Business Organizations mentions "pre-existing compliance programs" and the SEC in the so-called Seaboard report mentions "factors," the Chamber believes these are not specific enough to be helpful. ${ }^{182}$ They are seeking more than a recitation of the elements of a good program. ${ }^{183}$ The Chamber wants guidance that establishes "standards that businesses may adopt and incorporate as part of their compliance programs, and [that] identify the specific components that the Department and SEC consider to be essential to a robust FCPA compliance program." ${ }^{184}$ This is difficult to quantify.

2. Parent-Subsidiary Liability: The Chamber argues that the SEC has taken a position, although not tested in court, that "a parent company can be liable for a subsidiary's violations of the anti-bribery provisions even when the subsidiary's improper acts were undertaken without the parent's knowledge, consent, assistance or approval . . . "185 This has caused consternation and no doubt adds to the costs of due diligence in acquisitions. ${ }^{186}$

3. Successor Liability: The Chamber is concerned with Opinion Release 08-02 and the implications for pre- and postacquisition due diligence, which seemingly required extraordinary measures to avoid criminal prosecution. ${ }^{1}$

4. De Minimis Gifts and Hospitality: The Chamber disputes the claim that the DOJ does not prosecute de minimis cases. ${ }^{188}$ They argue for specific examples akin to the Guidance offered as part of the UKBA. ${ }^{189}$

181. Id. (citing United States v. Aguilar, 831 F. Supp. 2d 1180 (C.D. Cal. Feb. 28, 2011) ("Lindsey Manufacturing" case) and United States v. Carson, No. 8:09-cr-00077-JVS (C.D. Cal. Feb. 21, 2011).

182. Id. at 4 .

183. Id.

184. Letter to the Honorable Lanny A. Breuer, supra note 178.

185. Id. at 6.

186. Id.

187. Id. at 6 .

188. Id. at 7 .

189. Id. 
5. Mens Rea Standard for Corporate Criminal Liability: Is it possible for a Company to be guilty of a crime even when no one in the company is charged and when no one is "in authority"? 190

6. Declination Decisions: If the DOJ made known their decisions about declining to prosecute albeit without identifying company information, this could be helpful for companies in the same way that Opinion Releases are (at least theoretically) helpful except that there are only fifty-six of these. If every declination summary were published, companies could follow trends. ${ }^{191}$

7. Other Issues: These include situations involving relatives of a government official, charity organizations' ties with officials, and apprentice programs to a customer where a government has an interest. ${ }^{192}$

Based upon the legislative hearing in 2011, the DOJ did not seem receptive to any of these matters. Yet the Guidance has assuaged some fears that the UK law will be applied in a way to entrap legitimate and law abiding companies, so a similar interpretative statement from the DOJ would lessen the anxiety that unnecessary dollars will be spent documenting what a company has lawfully done.

\section{A SUGGESTED PROPOSAL}

Amending the FCPA would be a fruitless and quixotic exercise in this political climate. Neither party would waste political capital to do this for such an unclear goal of somehow "improving" the statute.

Instead, the DOJ has a clear opportunity to issue comprehensive guidelines embracing a "rule of reason" in enforcement of the FCPA and clarifying what would not trigger an enforcement action. The UKBA has been hailed as a much tougher law in part because it does not allow "facilitation payments" and has a broader reach of application. Yet its small enforcement budget has rendered it underwhelming in all but the apprehension it has generated in the business community and the business it has created for compliance consultants. Guidance need not go as far as the Chamber of Commerce has suggested but could be effective even if more limited. We suggest simply the following:

- Reiterate and clarify the legality of facilitation payments.

- This is a transitional strategy. Once enforcement picks up in other countries, companies will avoid these types of payments as well. Almost a majority of US companies already have chosen not to permit these legal payments. ${ }^{193}$ The financial limits of these payments should

190. Letter to the Honorable Lanny A. Breuer, supra note 178.

191. Id. at 9.

192. Id. at $9-10$

193. Cloudy with a Chance of Prosecution?, supra note 69. See also India's Chief 
be delineated and a process to record and monitor them should be set in place. (See Figure 2, page 143).

- Revise the Opinion Release Procedure.

- The Procedure should be revised to make it more inviting to companies to use. It could be made anonymous like HIV testing, or attorneys could make the request based upon an undisclosed client similar to the process for whistleblower complaints under the DoddFrank Act. ${ }^{194}$ The time to answer a request should also be shortened so that companies would be encouraged to use the process. Lastly, there should be a formal recognition and credit of the attempt to secure guidance in the Sentencing Guidelines unless there was a mischaracterization or a failure to follow what was outlined in the Opinion query.

- Clarify the affirmative defense of entertainment and travel promotional expense by way of example to both developing countries and developed countries. Would dinner at Lutece and Yankees ticket be allowed? Olympic tickets? A week's worth of Olympic tickets?

- Publish "Declination" decisions thereby giving guidance on what was deemed to not trigger prosecution. Currently these decisions are reported anecdotally in the paper and not available for easy review.

- Clarify who is a "foreign official" through a list of examples culled from the Opinion Procedure letters as well as by incorporating answers to questions raised in the hearings and letter from the Chamber to the DOJ.

- Make clear that a compliance program with reporting could be used as a defense in any case and used to show the company's genuine efforts to address problems. Does it make sense for companies to focus so many hours on compliance issues (more than $100,000)$ given the economic slowdown?

- Support best practices in industry. For example, let companies support conferences for doctors who may also be foreign officials attending a conference for medical continuing education.

\section{CONCLUSION}

We do not condone corruption and do not in any way advocate abandoning the push to eradicate corruption and bribery on a global level. One need not look far to identify examples of harm caused by awarding

Economic Advisor Wants to Legalise Some Kinds of Bribe Giving, EconOMIST, May 7, 2011, at 80 , available at http://www.economist.com/node/18652037 (discussing Kaushik Basu's idea of making "harassment bribes" where you have to pay "to get things to which [you are] legally entitled" and granting immunity and encouraging complaint filing).

194. Dodd-Frank Wall Street Reform and Consumer Protection Act, Pub. L. No. 111 203, 124 Stat. 1376 (2010). 
contracts to the highest briber as opposed to the entity most qualified to provide the good or the service. In a recent examination of the effects of bribing on business, Professor Elizabeth Spahn suggests the following as examples of real harm to real people that are likely caused by bribery:

Fifty-one people died from contaminated toothpaste manufactured abroad. Fake baby formula killed dozens of infants. Lead and other toxins are found in children's toys manufactured abroad. Dogs and cats died after consuming pet food poisoned with melamine. Vast amounts of imported drywall used in residential home construction in America turned out to be so contaminated with toxins that the homes are literally uninhabitable. ${ }^{195}$

Other experts concur. In a dramatic talk, Dennis McInerney, Chief of the Fraud Section of the DOJ, pointed to a singed "baby warmer" and alluded to the burns and scarring suffered by premature babies in an unnamed developing country who were placed in defective incubators purchased by corrupt hospital administrators.

Professor Philip Nichols outlines more structural harms caused by corruption based on bribery: weaker governments that make poor decisions, a distorted decision-making process, economic fragility, weakened connection between the government and its people and decreased quality of life. ${ }^{197}$ It is generally agreed that a high incidence of bribery is associated with low economic growth, ${ }^{198}$ and some suggest that in fact bribes are like "sand in the wheels" and human safety concerns are at stake in considering the issue of bribery. $^{200}$

195. Elizabeth Spahn, Nobody Gets Hurt?, 41 GEO. J. INT'L L. 861, 893-94 (2010) (citations omitted) (offering a thoughtful analysis of the harms generated by bribes in the global marketplace).

196. Dennis McInerney, Chief, Dep't of Justice Fraud Section, Luncheon Speaker at The Third Annual National Institute on the Foreign Corrupt Practices Act, AMERICAN BAR Association, Washington, D.C. (Oct. 21, 2010) (notes on file with authors).

197. Philip M. Nichols, The Psychic Costs of Violating Corruption Laws, 45 VAND. J. TRANSNAT'L L. 145, 156-66 (2012) (study of bribery based on discussions about bribery with relevant actors in Singapore and Malaysia).

198. Spahn, supra note 195, at 870-71 (citations omitted).

199. See Pierre-Guillaum Meon \& Khalid Sekkat, Does Corruption Grease or Sand the Wheels of Growth?, 122 PUBLIC CHOICE 69 (2005) (concluding that corruption has a negative impact on both growth and investment).

200. Robert Amaee, Head of the Anti-Corruption and Proceeds of Crime Units at the Serious Fraud Office (U.K.), Speech at World Bribery and Corruption Compliance Forum (Sept. 14, 2010), available at http://www.sfo.gov.uk/about-us/our-views/otherspeeches/speeches-2010/world-bribery-and-corruption-compliance-forum.aspx. 
Yet, global reform need not require demonizing companies trying to make a legitimate profit in the still-imperfect global marketplace. Business should not be branded as the enemy in the current environment; rather, government needs to work with the private sector to clarify the FCPA legislation. The law's open invitation to work within existing systems as necessary to accomplish the business need leaves enormous discretion to the criminal division of the DOJ, which has proved to be a rather ineffective and inefficient arbiter of late. We can agree that millions of dollars in government resources should neither be used pursuing de minimis issues nor for branding individuals and companies as criminal for making subjective decisions with which the government disagrees. ${ }^{201}$

Given that statutory change is unrealistic, the United States might be wise to borrow the United Kingdom's two-fold strategy of issuing "guidance" and focusing on the most serious cases while (presumably) giving credit for genuine efforts made by businesses to restrict improper payments. As we have pointed out, the companies most able to afford it have adopted the policy of forbidding any payments at all. According to one industry executive, these policies are taken very seriously: a tip for a delivery to the home is permissible while any person making any delivery to the corporate office must walk away empty-handed. This is a global policy applicable to the US public servant, the letter carrier, as strongly as to the foreign public servant charged with arranging for goods to be transferred on the dock. ${ }^{202}$ Another example of the move toward zero tolerance is evident in pharmaceutical giant AstraZeneca's policy on marketing to healthcare professionals unveiled in April of 2011, which aims to establish "global standards of ethical sales and marketing practice"203 and to support those efforts through training, reporting, and compliance efforts. ${ }^{204}$ With respect to marketing to physicians, the new policy is that the company will "no longer pay for delegate registration, accommodation and other associated costs for healthcare professionals or other external people to attend meetings .... We only cover travel costs to local meetings and conferences where the cost is minimal. ${ }^{, 205}$ Creative means to bring the

201. Cf. David Zucchino, Closing Arguments in John Edwards Trial, L.A. TimEs, May, 18, 2012, available at http://articles.latimes.com/2012/may/18/nation/la-na-john-edwards20120518 (quoting the former lead lawyer for Senator John Edwards: "This is a case that should define the difference between someone committing a wrong and committing a crime ... the difference between a sin and a felony"; Edwards was found not guilty on one charge and there was a hung jury on the other charges).

202. Interview with C-level compliance officer at a major pharmaceutical company (on file with authors).

203. Sales and Marketing Practice, ASTRAZENECA, http://www.astrazeneca.com/ Responsibility/Sales-and-Marketing-Practice (last visited Feb. 15, 2013).

204. Id.

205. Marketing to Healthcare Professionals, ASTRAZENECA, http://www.astrazeneca.com/ Responsibility/Sales-and-Marketing-Practice/Marketing-to-healthcare-professionals (last visited 
education to physicians otherwise unable to attend educational conferences are being explored, including providing video and podcast links on a limited basis. ${ }^{206}$

The more serious issue is the obstacles faced by the small- and medium-sized businesses without the resources to adopt and enforce blanket prohibitions. In these cases, the guidance and clarity together with recognition for genuine efforts may offer a balance to the uneven scale of justice. Given that any facilitation payments as well as promotion and hospitality payments must be recorded as such, proactive emphasis on accurate record keeping would serve to incrementally move the needle toward creating a more transparent environment. The pharmaceutical industry's recent emphasis on public disclosure of all payment, reached through both internal and external pressure, might serve as a model for other business transactions.

In the final analysis, it might be the court of public opinion that finally decides when a bribe is not a bribe. ${ }^{207}$

\section{POSTSCRIPT}

In November 2012, the Department of Justice issued the long promised "Resource Guide to the U.S. Foreign Corrupt Practices Act" (Guide). ${ }^{208}$ The purpose was to provide additional information to businesses and individuals on compliance with the FCPA. The DOJ stated:

[t] he Guide takes a multifaceted approach, setting forth in detail the statutory requirements while also providing insight into DOJ and SEC enforcement practices through hypotheticals, examples of enforcement actions and anonymized declinations, and summaries of applicable case law and DOJ opinion releases. ${ }^{209}$

While the Guide is not groundbreaking, it is useful because the DOJ and SEC attorneys, in this ninety page document with 418 footnotes, $t$,

Feb. 15, 2013).

206. Id.

207. Cf. Roger Clemons Acquitted on All Charges in Perjury Trial, CBS NEws, June 18, 2012, http://www.cbsnews.com/8301-400_162-57455533/roger-clemens-acquitted-on-all-chargesin-perjury-trial/ (noting the jury's rejection of the prosecution's view of Clemens' actions as crimes); SEC Adopts Rules to Establish Whistleblower Program, SECURITIES \& EXCHANGE COMM'N, May 25, 2011, http://www.sec.gov/news/press/2011/2011-116.htm.

208. A Resource Guide to the U.S. Foreign Corrupt Practices Act, DEP'T OF JUSTICE / SEC. \& EXCH. COMM'N, Nov. 14, 2012, http://www.justice.gov/criminal/fraud/fcpa/guide.pdf [hereinafter Guide]; see also Press Release, SEC and Justice Department Release FCPA Guide, SEC. \& EXCH. COMM'N, Nov. 14, 2012, http://www.sec.gov/news/press/2012/2012225.htm.

209. Press Release, supra note 1. 
bring together examples from recent prosecutions, plea bargains, opinion releases and cases. It could be a helpful compilation because the information is not easily accessed in one place and reflects the government's position at this time.

The Guide addresses the long expressed concern ${ }^{210}$ that companies have to spend money defending giving a cup of coffee to a foreign official. The Guide states:

This is difficult to envision any scenario in which provision of cups of coffee, taxi fare, or company promotional items of nominal value would ever evidence corrupt intent, and neither DOJ nor SEC has ever pursued an investigation on the basis of such conduct. DOJ's and SEC's enforcement actions have focused on small payments and gifts only when they comprise part of a systemic or longstanding cause of conduct that evidences a schema to corruptly pay foreign officials to obtain or retain business. These assessments are necessarily fact specific. ${ }^{211}$

An example of how this Guide may be helpful is in the discussion under the heading of "Cash" in Section 2 under the Anti-Bribery heading. ${ }^{212}$ Included in this section (without footnotes so it is unclear whether they are hypotheticals or from investigations) " $\$ 12,000 \ldots$ [for] visits to wineries and dinners ... $\$ 10,000 \ldots$ on dinners and drinks, and entertainment ... a trip to Italy for eight Iraqi government officials that consisted primarily of sightseeing and included $\$ 1,000$ in "pocket money" for each official ... a trip to Paris for a government official and his wife ... [with] touring... via a chauffeur-driven vehicle."213

There are more specifically listed examples with footnotes of improper expenditures like two week trips for sightseeing and not training purposes and included $\$ 500$ to $\$ 1000$ a day in spending money. ${ }^{214}$ Also in this section is a list of nine instances that could be helpful in distinguishing what are "reasonable and bonafide expenditures." 215 These nine instances are drawn from Opinion Releases. There has not been a great deal of analysis of Opinion Releases, excluding this paper, so one strength of the Guide is that its authors have tried to discern important rules of conduct

210. See Foreign Corrupt Practices Act: Hearing, supra note 157 (seemingly referencing a comment made by Deputy Assistant Attorney General Greg Andres stating that no one had been prosecuted for giving another a cup of coffee).

211. Guide, supra note 208 , at 15.

212. Id. at $15-16$.

213. Id. at 16 .

214. Id.

215. Id. at 24 . 
from these Opinion Releases. As an example, the Guide lists "Do not select the particular officials... or else select them based on predetermined, merit based criteria",216 or "Do not... pay ... cash",217 and "Pay ... directly to ... vendors ....",218

In Section 3 (the Accounting provisions), there is a list without footnotes that categorizes how bribes have been "mischaracterized," essentially itemizing red flags. ${ }^{219}$ The list includes: "Commissions or Royalties, Consulting Fees, Sales and Marketing Expenses, Scientific Incentives or Studies, Travel or Entertainment Expenses, Rebates or Discounts, after sales service Fees, Miscellaneous Expenses, petty Cash Withdrawals, Free Goods, Intercompany Accounts, Supplier/Vendor Payments, Write-offs, 'Customs-Intervention' Payments.,220 The Guide points out that without adequate controls, there are likely to be other consequences besides potential FCPA violations, noting "(c)ompanies with ineffective internal controls often face risks of embezzlement and selfdealing by employees, commercial bribery, export control problems, and violations of other U.S. and local laws.,"221

The use of case studies without footnotes although not precedent or controlling, does give counsel more illustrations of current DOJ analysis. There is a disclaimer in the beginning of the Guide providing that "it does not in any way limit the enforcement intentions or litigating positions of the U.S. Department of Justice, the U.S. Securities and Exchange Commission, or any other U.S. government agency.,222 Yet if a company did exactly what was outlined in the Guide, it could be very helpful in negotiating with the DOJ or SEC. The "Compliance Program Case Study"223 makes reference to a financial institution's robust compliance program and a declination of prosecution against that institution, which had not uncovered a Chinese official's deception about his personal ownership of a SPV (special purpose vehicle). The section does offer a helpful examination of declinations by the DOJ and the SEC. - five public companies and one private company. ${ }^{224}$ Justification for declinations include a company's active involvement in compliance, self -reporting, follow up to set the situation right, internal disciplinary action including termination of responsible employees and improved training and monitoring. ${ }^{225}$

216. Id.

217. Guide, supra note 208 , at 24.

218. Id.

219. Id. at 39 .

220. Id.

221. Id. at 40 .

222. Id. at the second page of the document which is not numbered.

223. Guide, supra note 208 , at 61 .

224. Id. at 77-79.

225. Id. 
The initial reaction to the Guide has been mixed. ${ }^{226}$ The longanticipated document is not groundbreaking in providing any new DOJ interpretations, but it does offer some modest assistance by having information collected in one place. article.

An exegesis of the Guide would be an appropriate subject of another J., Nov. 15, 2012, at B1 (discussing the reactions of both individuals and various groups to the Guide). 



\section{Indiana}

International

\& Comparative

Law Review vol. $23 \quad$ No. $2 \quad 2013$

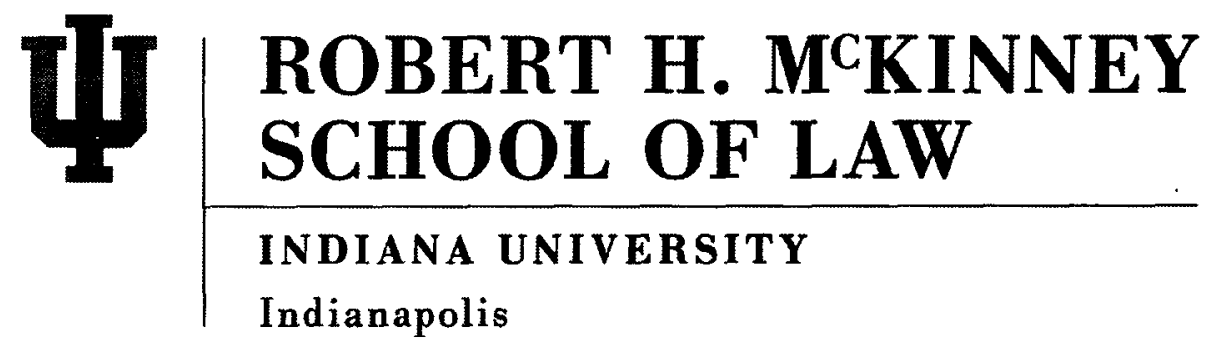

\section{Indiana University Robert H. McKinney School of Law}

Lawrence W. Inlow Hall, 530 West New York Street, Indianapolis, IN 46202 
The Indiana International and Comparative Law Review publishes professional and student scholarly articles in fields of international or comparative law. The Review welcomes submissions of scholarly legal articles on those topics.

The ideas, views, opinions, and conclusions expressed in articles appearing in this publication are those of the authors and not those of the Review or of Indiana University Robert H. McKinney School of Law.

Currently, the Review is published twice per year. The cost of a single issue is $\$ 9.00$, and subscription rate is $\$ 18.00$ per volume. The annual subscription rate for a foreign subscriber is $\$ 21.00$.

Inquiries regarding submission of articles and comments or subscription may be directed to:

Indiana International \& Comparative Law Review

Lawrence W. Inlow Hall

530 West New York Street

Indianapolis, IN 46202

(317) 274-1050

(317) $274-8825($ fax $)$

\section{COPYRIGHT AND FAIR USE}

Copyright $\mathbb{C} 2013$ by the Trustees of Indiana University

Except where expressly noted in this publication, permission is granted to reproduce, distribute, or display individual works from this publication in whole or in part for nonprofit educational purposes. All copies made, distributed, or displayed for such purposes must carry copyright notice of the author and the source of the work on every copy, and each copy may be distributed only at or below cost. The permission herein granted is in addition to rights of reproduction conferred by Sections 107, 108, and other provisions of the U.S. Copyright Act and its amendments.

The Review is printed and distributed by Western Newspaper Publishing, Inc., 537 E. Ohio St., Indianapolis, IN 46204-2173. 


\section{Indiana}

\section{International}

\section{\& Comparative \\ Law Review}

The Indiana International \& Comparative Law Review, published by the Indiana University Robert H. McKinney School of Law since 1991, is a studentedited law journal that provides a forum for the discussion and analysis of contemporary issues in public and private international law. The Review publishes articles by prominent legal scholars, practitioners, and policy makers around the world, as well as student-written notes and comments.

The Review is published twice annually, with a symposium issue devoted to a specific topic of international or comparative law published intermittently. Past symposium topics have included political and social aspects of Italian law, various aspects of Chinese law, and international terrorism in the twenty-first century.

Name

School/Firm/Business

Address

City, State, Zip Code

Subscriptions within the U.S. are $\$ 18.00$ per year and outside the U.S. are $\$ 21.00$ per year. I enclose $\$$ for subscription(s) to the Indiana International \& Comparative Law Review. Please make your check payable to the Indiana International \& Comparative Law Review.

Mail to: $\quad$ Executive Production Editor Indiana International \& Comparative Law Review Lawrence W. Inlow Hall 530 West Street

Indianapolis, IN 46202-3225 



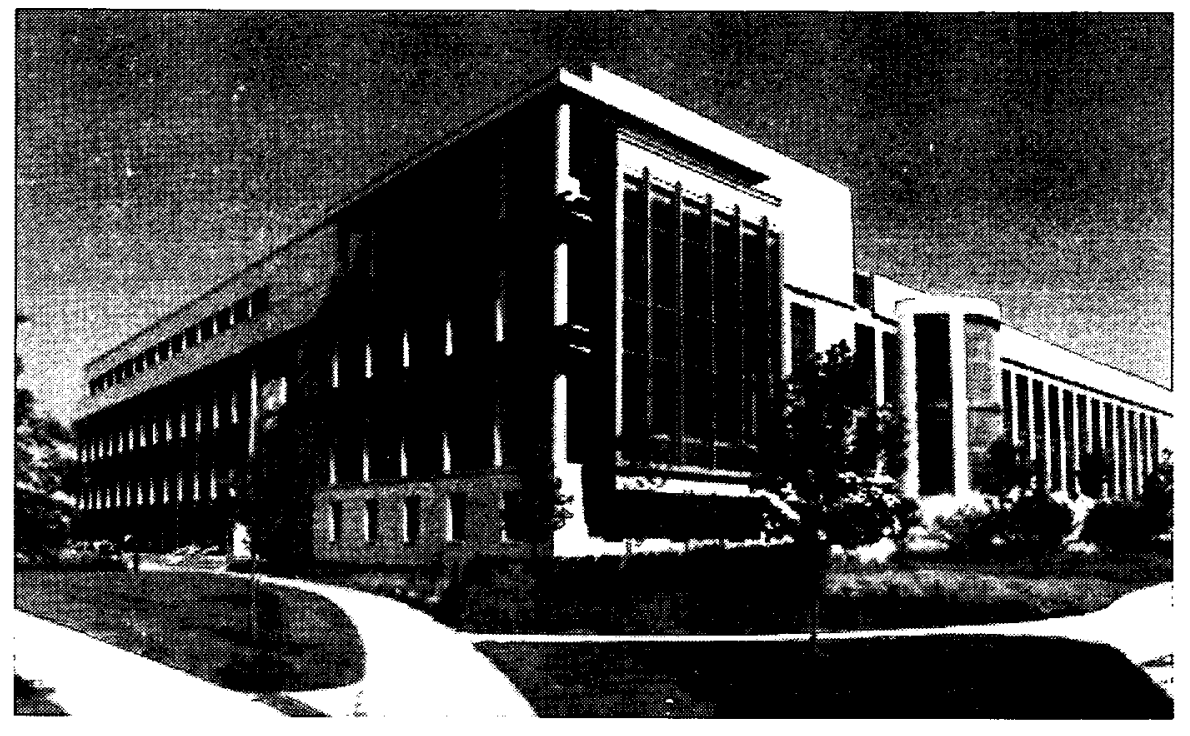

Please enter my subscription to the INDIANA LAW REVIEW

Name

Address

Enclosed is $\$$ for subscription(s)

Mail to: ATTN: Editorial Specialist at INDIANA LAW REVIEW INDIANA UNIVERSITY ROBERT H. MCKINNEY SCHOOL OF LAW Lawrence W. Inlow Hall 530 West New York Street Indianapolis, Indiana 46202-3225

For an academic year, the subscription rate for four issues is:

Domestic, \$30; Foreign, $\$ 35$; Student, $\$ 20$

Single Issue, $\$ 10$; Survey Issue $\$ 20$

Symposium Issue, $\$ 15$ 

In 2003, Indiana University Robert H. McKinney School of Law established a specialty law review focused specifically on health care law and policy:

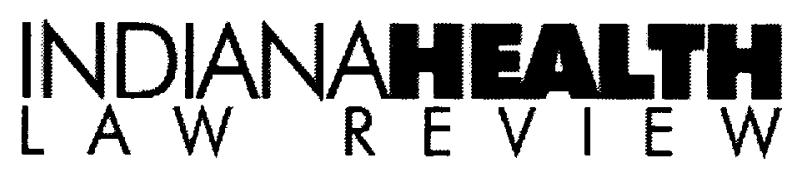

The scope of the INDIANA HEALTH LAW REVIEW includes bioethics, malpractice liability, managed care, anti-trust, health care organizations, medical-legal research, legal medicine, food and drug, and other current health-related topics.

Detach and mail this subscription form today to receive future issues

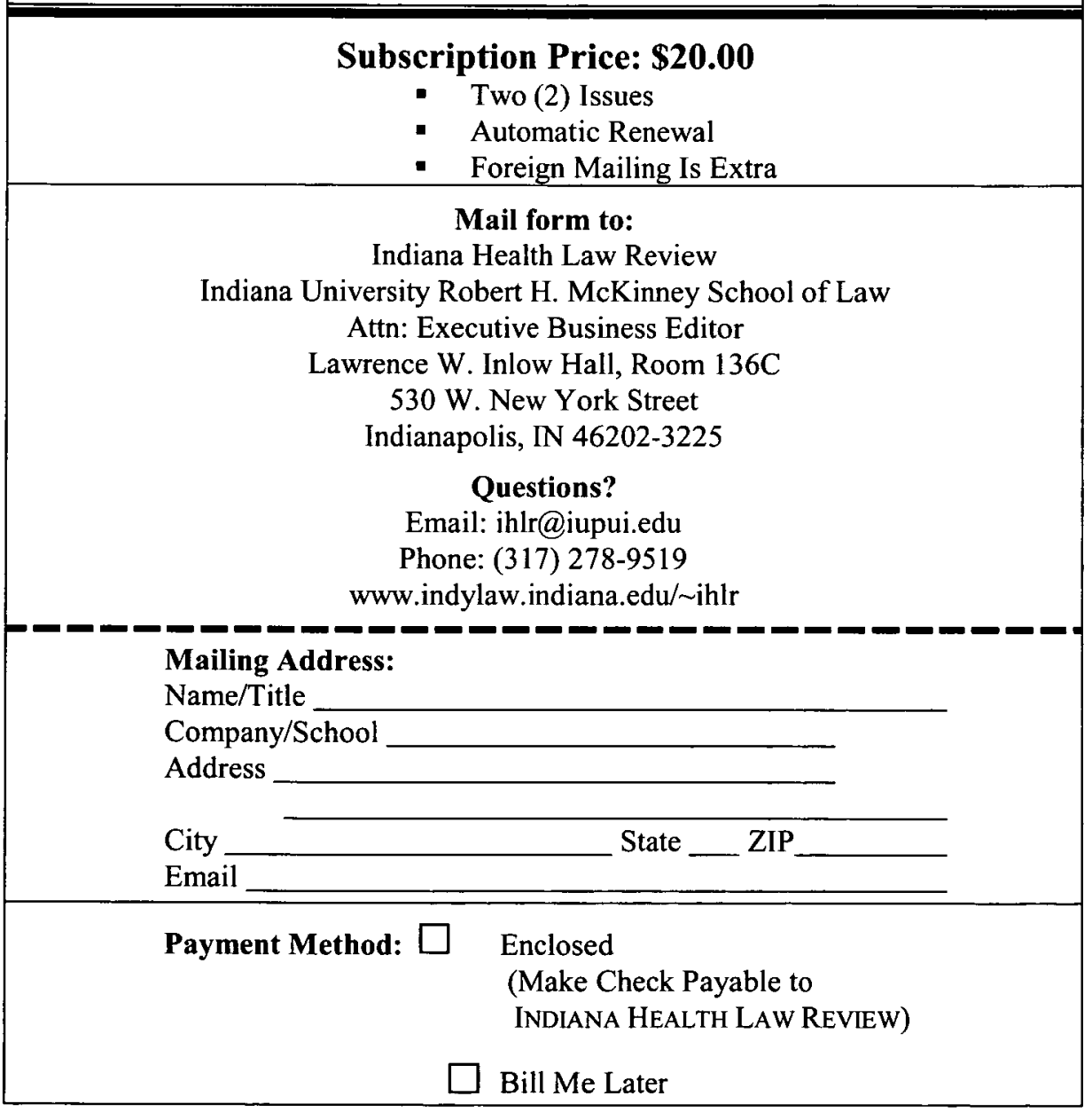


. 


\title{
Indiana University Robert H. McKinney School of Law 2012-2013 ADMINISTRATIVE OFFICERS AND FACULTY
}

\author{
Administrative Officers
}

Michael A. McRobbie, President of the University. Ph.D., Australian National University.

CHARLES R. BANTZ, Chancellor, Indiana University-Purdue University-Indianapolis; Indiana University Executive Vice President. B.A., M.A., University of Minnesota; Ph.D., Ohio State University.

GaRY R. ROBERTS, Dean and Gerald L. Bepko Professor of Law. B.A., Bradley University; J.D., Stanford University.

Antony Page, Vice Dean, Professor of Law and Dean's Fellow. B. Comm., McGill University; M.B.A., Simon Fraser University; J.D., Stanford Law School.

Karen E. BRAvo, Associate Dean for International Affairs, Professor of Law, John S. Grimes Fellow; Dean's Fellow. B.A., The University of the West Indies; J.D., Columbia University School of Law; LL.M., New York University School of Law.

Gerard N. MagliocCa, Associate Dean for Research, Samuel R. Rosen Professor of Law. B.A., Stanford University; J.D., Yale Law School.

JAMES P. NeHF, Associate Dean for Graduate Studies, Cleon H. Foust Fellow, John S. Grimes Fellow, and Professor of Law. B.A., Knox College; J.D., University of North Carolina Law School.

Jonna Kane MaCDougall, Assistant Dean for External Affairs and Alumni Relations, Adjunct Professor of Law. B.A., M.A., Indiana University; J.D., Indiana University Robert H. McKinney School of Law.

JohnNy D. Pryor, Assistant Dean for Student Affairs. B.A., Wittenberg University; J.D., Indiana University Maurer School of Law.

Chasity Q. Thompson, Assistant Dean for Professional Development. A.S., B.A., Alabama State University; M.B.A., Auburn University; J.D., Indiana University Robert H. McKinney School of Law.

MARK V. WUNDER, Assistant Dean for Development. B.S., J.D., University of Iowa.

JOHN R. SCHAIBLEY, III, Executive Director of the Center for Intellectual Property Law and Innovation and Adjunct Professor of Law. B.A., Purdue University; J.D., Indiana University Maurer School of Law.

ElizABETH AlLINGTON, Director of Communications and Creative Services. B.A., Indiana University; M.A., M. Phil., New York University.

TERESA (TERRI) J. CuelLaR, Director of Technology Services. B.S., St. Bonaventure University, New York.

BRANDT HERSHMAN, Director of Educational Outreach. Purdue University.

AMANDA Kamman, Director of Fundraising and Development Services. B.A., Indiana University.

PATRICIA K. KINNEY, Director of Admissions. B.S., Purdue University; J.D., Indiana University Robert $\mathrm{H}$. McKinney School of Law.

VIRGINIA MARSCHAND, Director of Administrative and Fiscal Affairs. B.S., Indiana University-Kokomo; M.P.A., Indiana University Purdue University-Indianapolis; J.D., Indiana University Robert H. McKinney School of Law.

SONJA RICE, Director of Special Projects. B.A., Purdue University; J.D., Indiana University Robert H. McKinney School of Law.

AMY K. SPEARS, Director of Major Gifts. B.A., Earlham College.

LAWANDA W. WARD, Director of Pro Bono and Public Interest Programs. B.A., Murray State University; M.A., Illinois State University; M.S., Old Dominion University; J.D., Indiana University Robert H. McKinney School of Law.

JACOB J. MANALOOR, Associate Director for Contracts, Grants \& Fundraising. B.S., Indiana University Purdue University-Indianapolis; J.D., Indiana University Robert H. McKinney School of Law.

ANTHONY MASSERIA, Associate Director for Graduate Programs. B.A., Hanover College; M.S. Ed. Indiana University. 
SEAN SoutHERn, Associate Director, Office of Professional Development. B.A., Ball State University; M.A., DePaul University; J.D., Loyola University Chicago School of Law.

Carlota Toledo, Associate Director of Student Affairs. A.B., University of Chicago; J.D., DePaul University College of Law.

SuSAN K. AGNEW, Assistant Director of Student Affairs. Clark College.

WILlIAM J. BAKER, Assistant Director of Technology Services. B.S., Purdue University.

SUSAN BuShUE-RUSSELL, Assistant Business Manager. A.A.S., Lakeland College; B.S., Eastern Illinois University

Amanda Gallaga, Assistant Director of Recruitment. B.A., Trinity University.

NOAH JOSEPH, Assistant Director for Graduate Studies. B.A. Miami University; J.D., Indiana University Maurer School of Law.

KAREN H. Miller, Assistant Director for Admissions. Midway College.

LISA SCHRAGE, Assistant Director for Donor Relations. B.S., Marian College.

\section{Faculty}

Cynthia M. Adams, Clinical Professor of Law. B.A., Kentucky Wesleyan College; J.D., Indiana University Robert H. McKinney School of Law.

JUDITH FORD ANSPACH, Professor of Law and Director, Ruth Lilly Law Library. B.S., M.L.S., Kent State University; J.D., Mississippi College School of Law.

CYNTHIA A. BAKER, Clinical Professor of Law and Director, Program on Law and State Government. B.A., J.D., Valparaiso University.

GERALD L. BEPKO, Indiana University-Purdue University-Indianapolis Chancellor Emeritus, Indiana University Trustee Professor and Professor of Law. B.S., Northern Illinois University; J.D., ITT/Chicago-Kent College of Law; LL.M., Yale Law School.

Shawn BoYne, Associate Professor of Law, Dean's Fellow; Grimes Fellow. B.A., Cornell University; M.B.A., University of Minnesota; J.D., University of Southern California's Gould School of Law, M.A., Ph.D., University of Wisconsin; LL.M., Justus-LiebigUniversität.

Robert Brookins, Professor of Law. B.S., University of South Florida; J.D., Ph.D., Cornell University.

JefFrey O. COOPER, Associate Professor of Law. A.B., Harvard University; J.D., University of Pennsylvania Law School.

ERIC R. Dannenmaier, Professor of Law, Dean's Fellow; Grimes Fellow. B.A., Drury College; J.D., Boston University; LL.M., Columbia University; M. St., Oxford University.

JAMES D. DIMITRI, Clinical Professor of Law. B.S., Indiana University; J.D., Valparaiso University School of Law.

Jennifer A. DrobaC, Professor of Law. B.A., M.A., Stanford University; J.D., J.S.D., Stanford Law School.

YvonNe M. DUTTON, Associate Professor of Law. B.A., Columbia University; M.A., University of Colorado at Boulder; Ph.D., University of Colorado at Boulder; J.D., Columbia Law School.

GeORge E. EdWARDS, Carl M. Gray Professor of Law; Faculty Advisor to the LL.M. track in International Human Rights Law; Director, Program in International Human Rights Law; John S. Grimes Fellow. B.A., North Carolina State University; J.D., Harvard Law School.

Frank Emmert, John S. Grimes Professor of Law and Executive Director, Center for International and Comparative Law. Erstes Juristisches Staatsexamen (J.D.), University of Munich Law School; LL.M., The University of Michigan Law School; Ph.D., University of Maastricht; Diploma, European University Institute.

Nicholas Georgakopoulos, Harold R. Woodard Professor of Law. Ptyhion Nomikis, Athens University School of Law; LL.M., S.J.D., Harvard Law School.

Carrie Hagan, Clinical Associate Professor of Law. B.A., University of Kansas; J.D., University of Cincinnati College of Law.

JOHN LAWRENCE HILl, Professor of Law. B.A., Northern Illinois University; J.D., Ph.D., Georgetown University. 
Max Huffman, Associate Professor of Law; Dean's Fellow. B.A., Cornell University; J.D., University of Cincinnati College of Law.

LAWrence A. Jegen, III, Thomas F. Sheehan Professor of Tax Law and Policy. B.A., Beloit College; J.D., M.B.A., University of Michigan; LL.M., New York University School of Law.

Robert A. Katz, Professor of Law. A.B., Harvard College; J.D., University of Chicago Law School.

Linda Kelly Hill, M. Dale Palmer Professor of Law. B.A., J.D., University of Virginia. MaX Huffman, Associate Professor of Law and Dean's Fellow. B.A., Cornell University; J.D., University of Cincinnati College of Law.

ANDREW R. KLEIN, Paul E. Beam Professor of Law; Chief of Staff, Office of the Chancellor of IUPUI. B.A., University of Wisconsin; J.D., Emory University School of Law.

Norman LefsteIn, Professor of Law and Dean Emeritus. LL.B., University of Illinois College of Law; LL.M., Georgetown University Law School.

ALlISON MARTIN, Clinical Professor of Law. B.S., J.D., University of Illinois.

Deborah MCGregor, Clinical Professor of Law and Assistant Director of Legal Analysis, Research and Communication. B.A., University of Evansville; J.D., Georgetown University Law Center.

EMILY MORRIS, Associate Professor of Law and Dean's Fellow. A.B., Harvard University; J.D., University of Michigan Law School.

Novella NedefF, Clinical Associate Professor of Law. B.A., J.D., Indiana University.

DAVID ORENTLICHER, Samuel R. Rosen Professor of Law and Co-Director of the William $S$. and Christine S. Hall Center for Law and Health. B.A., Brandeis University; J.D., M.D., Harvard University.

JOANNE ORR, Clinical Professor of Law. B.S., Indiana State University; J.D., California Western School of Law.

Michael J. PITTS, Professor of Law; Dean's Fellow and John S. Grimes Fellow. B.S.J., Northwestern University; J.D., Georgetown University Law Center.

Fran Quigley, Clinical Professor of Law, Health and Human Rights Clinic, Indiana University Robert H. McKinney School of Law; Senior Advisor, Indiana University Center for Global Health. B.A., Hanover College; M.A., Indiana University; J.D., Indiana University Robert H. McKinney School of Law.

Florence Wagman Roisman, William F. Harvey Professor of Law. B.A., University of Connecticut; LL.B., Harvard Law School.

JoAn M. RuHTENBERg, Clinical Professor of Law and Director of Legal Analysis, Research and Communication. B.A., Mississippi University for Women; J.D., Indiana University Robert H. McKinney School of Law.

MARGaret RyzNAR, Associate Professor of Law. B.A., University of Chicago; M.A., Jagiellonian University; J.D., University of Notre Dame Law School.

Joel M. SChUMm, Clinical Professor of Law. B.A., Ohio Wesleyan University; M.A., University of Cincinnati; J.D., Indiana University Robert H. McKinney School of Law.

Lea Shaver, Associate Professor of Law. B.A., M.A., University of Chicago; J.D., Yale Law School.

LAHNY R. SIlva, Associate Professor of Law. B.A., M.A., Boston University; J.D., University of Connecticut School of Law; LL.M., University of Wisconsin Law School.

Frank Sullivan, JR., Professor of Practice. A.B., Dartmouth College; J.D., Indiana University Maurer School of Law; LL.M., University of Virginia School of Law.

Margaret C. Tarkington, Associate Professor of Law. B.A., Brigham Young University; J.D., J. Reuben Clark Law School, Brigham Young University.

NiCOLAS P. TERRY, Hall Render Professor of Law; Co-Director of the William S. and Christine S. Hall Center for Law and Health. B.A., Kingston University; LL.M., Corpus Christi College, University of Cambridge.

Carlton MARK Waterhouse, Associate Professor of Law; Dean's Fellow. B.S., Pennsylvania State University; J.D. with honors, Howard University School of Law; M.T.S., Emory University, Chandler School of Theology; Ph.D. with honors, Emory University. 
FRANCES Watson, Clinical Professor of Law. B.S., Ball State University; J.D., Indiana University Robert H. McKinney School of Law.

Lloyd T. WILSON, JR., Professor of Law; Director, Joint Center for Asian Law Studies; Director, Chinese Law Summer Program; Director, American Law for Foreign Lawyers LL.M. Program. B.A., Wabash College; M.A., Duke University; J.D., Indiana University Maurer School of Law.

DIANA R.H. WINTERS, Associate Professor of Law. B.A., Brown University; M.A., Harvard University; Ph.D., Harvard University; J.D., New York University School of Law.

R. GEORGE WRIGHT, Lawrence A. Jegen III Professor of Law. A.B., University of Virginia; Ph.D., Indiana University; J.D., Indiana University Robert H. McKinney School of Law.

\section{Emeriti Faculty}

Thomas B. Allington, Professor of Law Emeritus. B.S., J.D., University of Nebraska; LL.M., New York University School of Law.

EdWARd P. ARChER, Professor of Law Emeritus. B.M.E., Renesselaer Polytechnic Institute; J.D., LL.M., Georgetown University Law School.

JameS F. BAIleY, III, Professor of Law Emeritus. A.B., J.D., M.A.L.S., The University of Michigan.

PaUL N. CoX, Professor of Law Emeritus. B.S., Utah State University; J.D., University of Utah College of Law; LL.M., University of Virginia School of Law.

CLYDE HARRISON CROCKETT, Professor of Law Emeritus. A.B., J.D., University of Texas; LL.M., University of London (The London School of Economics and Political Science).

Debra A. FAlender, Professor of Law Emerita. A.B., Mount Holyoke College; J.D., Indiana University Robert $\mathrm{H}$. McKinney School of Law.

David A. Funk, Professor of Law Emeritus. A.B., College of Wooster; J.D., Case Western Reserve University School of Law; M.A., The Ohio State University; LL.M., Case Western Reserve University; LL.M., Columbia Law School.

PaUl J. Galanti, Professor of Law Emeritus. A.B., Bowdoin College; J.D., University of Chicago Law School.

Helen P. Garfield, Professor of Law Emerita. B.S.J., Northwestern University; J.D., University of Colorado School of Law.

Harold Greenberg, Professor of Law Emeritus. A.B., Temple University; J.D., University of Pennsylvania Law School.

Jefrrey W. Grove, Professor of Law Emeritus. A.B., Juniata College; J.D., George Washington University Law School.

William F. HARVEY, Carl M. Gray Professor of Law \& Advocacy Emeritus. A.B., University of Missouri; J.D., LL.M., Georgetown University Law School.

W. William Hodes, Professor of Law Emeritus, A.B., Harvard College; J.D., Rutgers University School of Law-Newark.

William ANDREW KeRR, Professor of Law Emeritus. A.B., J.D., West Virginia University; B.D., Duke University; LL.M., Harvard Law School.

ElEANOR DEARMAn KINNEY, Hall Render Professor of Law, Co-director of the William $S$. and Christine S. Hall Center for Law and Health Emerita. B.A., Duke University; M.A., University of Chicago; J.D., Duke University School of Law; M.P.H., University of North Carolina.

WILlIAM E. MARSH, Professor of Law Emeritus. B.S., J.D., University of Nebraska.

SUSANAH M. MEAD, Professor of Law Emerita. B.A., Smith College; J.D., Indiana University Robert H. McKinney School of Law.

H. Kathleen PATChel, Associate Professor of Law Emerita. A.B., Huntington College; J.D., University of North Carolina Law School; LL.M., Yale Law School.

Ronald W. POLSTON, Professor of Law Emeritus. B.S., Eastern Illinois University; LL.B., University of Illinois College of Law.

KENNETH M. STROUD, Professor of Law Emeritus. A.B., J.D., Indiana UniversityBloomington. 
James W. TORKE, Carl M. Gray Professor of Law Emeritus. B.S., J.D., University of Wisconsin.

JAMES PATRICK WhITE, Professor of Law Emeritus. A.B., University of Iowa; J.D., LL.M., George Washington University Law School.

LAWRENCE P. WiLkINS, William R. Neale Professor of Law Emeritus. B.A., The Ohio State University; J.D., Capitol University Law School; LL.M., University of Texas School of Law.

MARY THERESe Wolf, Clinical Professor of Law Emerita. B.A., Saint Xavier College; J.D., University of Iowa College of Law.

\section{Ruth Lilly Law Library Faculty}

Judith FORD ANSPACH, Professor of Law and Director, Ruth Lilly Law Library. B.S., M.L.S., Kent State University; J.D., Mississippi College School of Law.

SuSAN DAVID DEMAINe, Research and Instruction Librarian. B.A., Pennsylvania State University; M.S.L.S., University of Kentucky; J.D., University of Kentucky.

DEBRA DENSLAw, Research and Instruction Librarian. B.A., Franklin College; M.S., University of Illinois, Urbana-Champaign; J.D., Valparaiso School of Law.

RICHARD HUMPHREY, Reference Librarian. A.A., Brewton-Parker Junior College; B.A., Georgia Southwestern College; M.L.S., University of Kentucky.

Wendell E. Johnting, Cataloging and Government Documents Librarian. A.B., Taylor University; M.L.S., Indiana University.

BENJAMIN J. KEELE, Research and Instruction Librarian. B.A., University of NebraskaLincoln; J.D., Indiana University Maurer School of Law; M.L.S., Indiana University School of Library \& Information Science.

CATHERINE LEMMER, Head of Information Services. B.A., Lawrence University; J.D., University of Wisconsin; M.S., University of Illinois.

CHRIS E. LONG, Cataloging Librarian. B.A., Indiana University; M.A., Indiana University; M.L.S., Indiana University.

MIRIAM A. MURPHY, Associate Director. B.A., Purdue University; J.D., M.L.S., Indiana University-Bloomington. 



\section{ROBERT H. MCKINNEY SCHOOL OF LAW}

INDIANA UNIVERSITY

Indianapolis

Indiana International \& Comparative Law Review, Volume XXIII

Editor-in-Chief

ANNE C. KAISER

Executive Managing Editor

JENNA GERBER

Executive Notes Development Editor

ANNE MEDLIN

Executive Articles Development Editor

SPARDHA SAROHA

Executive Symposium Editors

DOUGLAS LOUKS

MORGAN WHITACRE

Article Editors

MiCHAEL BLACKWELL

CHRISTOPHER JACKSON

JIN KONG
Executive Production Editor

AleXANDER CRAIG

Executive Notes Editor NICOLE KELLER

Executive Articles Editor MAY LI

Student Note Editors

RICHARD MOHR

CHING-SHU WAGNER
ASSOCIATE MEMBERS

ROBERT BERCOVITZ

ELISA DOLL

\section{MEMBERS}

ZACHARY AHONEN

SUKRAT BABER

TARAH M.C. BALDWIN

JON BURNS

SEAN DENEAULT

DAVID DICKMEYER
ANDREW EMHARDT

KYLE FORGUE

SARAH HARRELL

KATELYN HOLUB

NICHOLAS JOHNSTON

MARIANNE LUU
Stephen ReEd

EMMA MAHERN

PATRICK MCINTYRE

KEATON MILLER

ALYSSA TAYLOR

LANE TUTtLE

GRAHAM YOUNGS 
Board of Faculty Advisors

KAREN BRAVO, CHAIRPERSON

ERIC R. DANNENMAIER

GEORGE E. EDWARDS

ANTONY PAGE

FRANK EMMERT

JOAN M. RUHTENBERG 